\title{
The structural reshaping of globalization: Implications for strategic sectors, profiting from innovation, and the multinational enterprise
}

\section{Olga Petricevic ${ }^{1}$ and David J Teece ${ }^{2}$}

\footnotetext{
${ }^{1}$ Strategy and Global Management Area and Entrepreneurship and Innovation Area, Haskayne School of Business, University of Calgary, Calgary, $A B$ T2N 1N4, Canada; ${ }^{2}$ Institute for Business Innovation, Haas School of Business, University of California, Berkeley, Berkeley, CA 94720-1930, USA

Correspondence:

O Petricevic, Strategy and Global Management Area and Entrepreneurship and Innovation Area, Haskayne School of Business, University of Calgary, Calgary, AB T2N 1N4, Canada

e-mail: o.petricevic@haskayne.ucalgary.ca
}

\begin{abstract}
The rapid reshaping of the global economic order requires fundamental shifts in international business scholarship and management practice. New forms of protectionist policies, new types of internationalization motives, and new tools of techno-nationalism may lead to what we call "bifurcated governance" at the macro-level and "value chain decoupling" at the micro-level. As a result, innovation networks will require novel reconfigurations. We examine the emerging constraints on multinational enterprises, imposed by a bifurcated world order. We also discuss how the dynamic capabilities framework can guide scholars and managers alike to achieve new forms of evolutionary fitness.
\end{abstract}

Journal of International Business Studies (2019) 50, |487-1512.

https://doi.org/10.1057/s41267-019-00269-x

Keywords: shaping globalization trajectories; MNE-host country relations; profiting from innovation; dynamic capabilities

The online version of this article is available Open Access

\section{INTRODUCTION}

The global economic system created in the post-World War II (WWII) era is now being disrupted and undergoing significant structural reshaping. While in need of improvement, the post-WWII system led to an extended epoch of peace and an unprecedented rise in prosperity. It lifted up, albeit unevenly, the welfare of much of the world's population as it encouraged enterprise formation and growth, brought investment, and, importantly, transferred advanced technology to many parts of the world. At the micro-level, the transfer of managerial best practices in a variety of functional areas, and in overall firm-level governance, may well have been the greatest contribution of the post-WWII system-in a downward cascading motion - to the functioning of the world economy, and it was brought about by multinational enterprise (MNE) investment and capability transfers (Dunning, 1958; Verbeke, Coeurderoy \&
Received: 14 January 2019

Revised: 15 August 2019

Accepted: 16 August 2019

Online publication date: 28 October 2019 
Matt, 2018). The unimpeded flow of best practice through micro-level governance transfers in turn contributed much to macro-level governance improvements (e.g., in the realm of portable, accounting transparency, and disclosure standards) in an upward cascading motion.

However, some are now suggesting that we have entered a period of 'de-globalization' (Livesay, 2018) undergirded by a technological 'cold war' (Ash, 2018; Kaplan, 2019). These developments are significantly impacting the tapestry of the international business (IB) landscape. They are requiring novel MNE strategies and novel approaches for theorizing about MNEs, and IB more generally. The ongoing reshaping at the macro-level has prompted some to suggest that MNEs will likely become "a passing episode in business history" (The Economist, 2017: 22). While this may be interpreted as hyperbole, it is a symptomatic manifestation of a larger phenomenon unfolding. As the world economy's globalization trajectory becomes increasingly uncertain, MNEs face pressures to re-examine their own 'global' value chains (GVCs), re-evaluate their cross-border investments strategies, re-assess their innovation and technology flows, and re-consider their strategic partnerships from a new perspective.

Until recently, a popular (albeit flawed) view was that cross-border activities had become so common and growing so significantly that the world was becoming 'flat' (Friedman, 2005; Rugman \& Oh, 2008). As the process of increasing cross-border integration accelerated during the 1990s, it highlighted the potential for 'diminished national autonomy' in the presence of growing technoglobalism (Ostry \& Nelson, 1995). It supposedly also created conditions for the emergence of metaMNEs (Lessard, Teece, \& Leih, 2016), neo-global corporations (Mees-Buss, Welch, \& Westney, 2019), and the view that the MNE could be a metaintegrator of knowledge and activities across multiple internal and external boundaries (Narula, 2017). This view assumed the continuation of an open or 'liberal' world economic order with low or no tariffs and investment controls, and respect for the rule-of-law in governance arrangements (Witt, 2019). Cooperation, mutual interdependence, and openness were hallmarks of the global system. Much of the scholarly work in IB has been built on these assumptions. Open innovation (Chesbrough, Vanhaverbeke, \& West, 2006), cooperative strategies (Beamish \& Lupton, 2016), global value chain orchestration (Gereffi, 2018), and global markets for know-how (Cano-Kollmann, Cantwell,
Hannigan, Mudambi, \& Song, 2016) were natural corollaries of this liberal system.

Notwithstanding this perspective, the IB scholarly community has been cognizant of long-standing institutional and structural differences throughout the global economy. In the 1950s, 1960s, and 1970s, scholars and practitioners alike were quite aware of political and governance differences, and made a very strong distinction between the state-planned (communist) and freemarket (capitalist)-based economies (e.g., Vernon \& Wells, 1986: 2). During this time, "[t]he idea of complex, cross-border configurations and the MNE as an integral part of the socio-economic milieu with a variety of dispersed activities was more science fiction than fact" (Cuervo-Cazurra \& Narula, 2015: 6).

Even with the end of the Cold War and the establishment of the World Trade Organization (WTO) in 1995, some IB scholars continued to emphasize heterogeneity among market-based economies leading to useful distinctions amongst 'varieties of capitalism' (VoC) (e.g., Jackson \& Deeg, 2008, 2019; Judge, Fainschmidt, \& Lee Brown III, 2014; Mariotti \& Marzano, 2019). The VoC approach implies that institutional features and complementarities along a particular spectrum either promote or constrain (and certainly affect the form of) MNEs' strategies, governance, innovation, and dispersion of value chain activities. While Amsden (2001: 2) noted that "[ $t]$ he rise of 'the rest' was one of the phenomenal changes in the last half of the 20th century," she explained this phenomenon by suggesting that those countries ${ }^{1}$ ascended "by devising an unorthodox, original economic model" (Amsden, 2001: 8) that could not be easily accommodated using existing classifications. This led to several attempts to classify 'Asian varieties of capitalism' in general (Storz, Amable, Casper, \& Lechevalier, 2013) and to understand better the opaque features of China's model of 'state capitalism' in particular (Hu, Cui, \& Aulakh, 2019; Naughton \& Tsai, 2015).

Others suggested that the vexing challenges of interdependencies and reciprocities in the global system could be better accommodated by the 'coreperiphery' $^{2}$ classification of the world economic order (Benito \& Narula, 2007). Specifically, Benito and Narula (2007: 3) noted that "membership of the core (and of the periphery) changes over time" and that 'core-periphery' should be treated as a continuum facing a constant state of flux. All of the above perspectives are consistent with Ghemawat's 
(2003) view that the world has only ever been semiglobalized and that nation states continue to play a critical role in shaping and re-shaping the competitive IB landscape. However, one weakness of the above frameworks and classifications is that they rely on path dependencies in extant institutional structures that cannot easily accommodate radical changes outside of the well-established continuum they focus on.

Today, we face a new milieu of structural reshaping of the global economic system. The developments we observe are challenging the existing norms and rules that have guided much of our scholarly work and have informed practice thus far. As a result, some perceive new ecologies of IB, as well as new classifications and mutations of firms operating in the new system (Mathews, 2006; Narula, 2006). For example, the emergence of new players on a global stage, such as 'springboard' MNEs (Luo \& Tung, 2018), new types of internationalization motives (Cuervo-Cazurra \& Narula, 2015), and the resurgence of techno-nationalism by nation states (Cantwell, Dunning, \& Lundan, 2010) are revealing new boundary conditions for our existing frameworks and classifications (Hernandez \& Guillén, 2018; Witt, 2019). We will focus, in this perspective article, on what we consider the single, most critical driver of radical change in the global economic order. Specifically, our main research question is how one powerful force at the macro-level, namely (neo) techno-nationalism, has been able to rapidly reshape the structure of the global economic order, and create cascading effects, requiring new responses from rule-of-law countries and a rethinking by MNEs on how to develop and deploy their dynamic capabilities (DCs)?

We begin this article by reviewing some of the 'macro' changes to the global economic system that are both structural and qualitative in nature. They are driven by political economy dynamics that cascade through all membranes of the IB ecosystem. Specifically, we examine the instruments of (neo) techno-nationalism that are at the root of new challenges to the world economy's globalization trajectory. Neo techno-nationalism is creating a new, bifurcated world order with some country regimes building innovation capacity on the basis of international intellectual property protection (rule-of-law countries), and other country regimes intentionally circumventing such protection and thriving on international technology acquisition by any means possible (typically autocratic countries). We highlight the increased importance of volatility, the proliferation of uncertainty, the rise of complexity and intensification of ambiguity (i.e., VUCA conditions) that characterize the new IB environment (van Tulder, Verbeke \& Jankowska, 2020). We discuss the differential impact on 'strategic' sectors that are at the core of developing new general-purpose and enabling technologies. Further, we examine how amplification of VUCA conditions requires MNEs to develop and deploy DCs (i.e., sensing, seizing, and reconfiguring) (Teece, 2007, 2014) in order to continue profiting from their innovations. We discuss how developing new types of DCs will require MNEs to consider explicitly multilateral and multi-stakeholder engagements, both to achieve evolutionary fitness with the new IB environment, and (potentially) to help shape the new IB landscape. We conclude the paper by issuing a call for action to the IB scholarly community to be aware of the substance and texture of the issues and to re-assess and enhance its current toolbox for navigating the new IB realities.

\section{RESHAPING GLOBALIZATION: THE RISE OF A BIFURCATED WORLD ORDER}

Many anticipated greater convergence of norms and values amongst nation states as globalization advanced. That expectation is no longer viable, and divergence among nation states, as to how the world economy should be shaped, is increasingly evident (Lundan, 2018; Ozawa, 2019; Witt, 2019). Scholars, executives and government officials alike, have been slow to realize the impact of these new, diverging prescriptions on how the world economy should be reshaped. At the micro-level, the ongoing reshaping is fundamentally altering the ability of MNEs to compete successfully in this new environment. Mainstream thinking on DCs implicitly assumes positive, non-zero-sum interdependencies among nations' and firms' actions, at least as far as innovation and novel resource combinations are concerned (and apart from possible conflicts in the realm of well-understood distributional income effects and crowding-out impacts that may arise from MNE activity). This thinking, however, may no longer be valid.

The view of a frictionless, homogeneous, rule-of$\mathrm{law}^{3}$ borderless world and a global, leveled playing field, despite differences with respect to state involvement, and geographic, cultural, administrative, and economic distances (Friedman, 2005; Ghemawat, 2007) is now clearly an illusion. The 
creation and acceptance of WTO rules to guide global commerce, and thus foster globalization, was never fully triumphant. Verbeke et al. (2018: 1102) suggest that "regionalization, as well as localized clustering in narrow geographic space, is often more relevant than globalization." It is increasingly apparent that the proposition that globalization has negated the power of nation states and that "state authority ... seems even to have ... just evaporated," (Strange, 1996: 56), is a myth.

Of course, the IB community was never of the view that 'distance' had disappeared and that national boundaries do not matter. Ghemawat (2003: 150) suggested more than 15 years ago: "it seems unlikely that increases [in cross-border integration] will any time soon yield a state in which the differences among countries can be ignored." In fact, Verbeke et al. (2018: 1103) point out in their recent JIBS editorial that "the simple observation still remains that most of even the world's largest firms are incapable of emulating the same level of home region success ... throughout the world, because "distance" does continue to matter." While globalization has made geographic distance less significant, the economic, political, structural, and especially technological, distances and boundaries between and amongst countries and regions are complex and continue to persist (e.g., Filippaios, Annan-Diab, Theodoraki, \& Hermidas, 2019; Jackson \& Deeg, 2019; Peterson, Søndergaard, \& Kara, 2018). This is increasingly requiring development and deployment of MNE capabilities that are context-specific.

Not only are national boundaries still important, the national identity of firms still matters. 'Dragon' MNEs $^{4}$ (Mathews, 2017) as well as 'springboard' MNEs (Luo \& Tung, 2018) are growing both in size and importance on the global economic stage by developing and deploying non-traditional firmspecific advantages (FSAs), including DCs (i.e., FSAs reflecting more than extant resource bundles, to include the continuous and systemic recombining of these with new resources) that in turn enable them to better leverage their country-specific advantages (CSAs) during internationalization (Bhaumik, Driffield, \& Zhou, 2016). Indian, Brazilian, and Chinese companies are rapidly building up innovation capabilities and transitioning at unprecedented speed from a production-focus to an innovation-focus (Altenburg, Schmitz, \& Stamm, 2008; Lema, Quadros, \& Schmitz, 2015), altering our views of traditional innovation clusters and trajectories (Asheim \& Coenen, 2005; Engel,
2015). Importantly, China is significantly shaping the 'globalization of innovation' trajectory of the world economy (Kennedy, 2017; Zhou, Lazonick, \& Sun, 2016). Based on the "Science and Engineering Indicators $2018^{\prime \prime}$ issued by the National Science Foundation (NSF) and National Science Board (NSB), China has become a technical and scientific superpower, and may have eclipsed the U.S. in scientific research output in some key fields.

Some have argued that there have been ongoing changes in the balance of global powers in the last two decades, and that the locus of economic power may have shifted to a state where there is a power vacuum in which no single country (or constellation of countries) is willing or able to provide global leadership (Bremmer \& Roubini, 2011; Casson \& Associates, 1986). These shifts are especially acute in the technological and innovation spheres (Atkinson \& Ezell, 2012).

While it is beyond the scope of this paper to predict in detail the contours of the new global structure that might emerge from the existing reshaping of the world economy, it is important to point out that the roles of nation states on the IB stage are in the process of not fading but strengthening. In short, sovereignty is not held 'at bay' by MNEs as Vernon (1971) had concluded almost half a century ago. Rather, the MNEs are held 'at bay' by strategic interventions of nation states, coupled with a decline in the rule-of-law and in what Jannace and Tiffany (2019) call a corresponding advance in the 'rule of rulers.' We see the possibility of a 'bifurcated world' arising with an increase in conscious decoupling of firms' and nations' objectives as well as economic and innovation trajectories. In this bifurcated world, the rule-of-law reflects a default predisposition toward transparent, arm's length relationships between firms and their homecountry governments, even if political preferences may be expressed in favor of domestically owned and controlled companies, domestic employment, domestic value creation, domestic taxation income, and domestic firms voicing allegiance to their home base. In contrast, in autocratic regimes where the rule-of-rulers prevails, the default predisposition is one of systematically discriminating against foreign firms, and championing domestic incumbents. In a recent commentary, Ozawa calls for research efforts in understanding how MNEs should re-adapt to the sudden changes in governance of the global system, as "ecosystem governance has recently turned into an unpredictable variable from a reliable constant for 
business decision making" (2019: 191, emphasis in original).

\section{The Erosion of the Global Rule-of-Law Economic Governance}

Most concerning in the above-illustrated developments is the noticeable defiance of the principles of classical economic liberalism ${ }^{6}$ and the rule-of-law. For example, Russian President Vladimir Putin, in an interview with the Financial Times, declared that liberalism has "outlived its purpose" (Barber, Foy, \& Barker, 2019). With respect to China, some argue that "China's system of governance treats law as an instrument of the state," and that "[t]he rule of law as it is understood in the West ... has simply failed to materialize ... since China joined the WTO" (Jannace \& Tiffany, 2019: 1393). In the recent World Justice Project 2019 report that measures the Rule of Law Index ${ }^{7}$ for 126 countries worldwide, China is ranked 82nd (which is its lowest (worst) ranking thus far).

Given the importance we place conceptually on the rule-of-law, we need to make clear that we are not talking about any system of law. We are referring to a system in which government decisions require applying legal and moral principles in a non-discriminatory way. Classical rule-of-law prevents the arbitrary use of governmental power or misappropriation of intellectual property rights (IPRs). ${ }^{8}$ In contrast, China's alternative model of governance is deploying coordinated protectionist trade and investment policies and government intervention aimed at accessing and acquiring foreign intellectual property, thereby influencing the global economic and innovation system.

In a historical context, the Western approach to the rule-of-law and the protection of IPR is deeply rooted in an individualist culture that emphasizes individual success and competition, and in the western European heritage of protecting ownership of copyrights and patents that goes back to the 14th and 16th century (Hart \& Fazzani, 1997). In contrast, China's approach has deep roots both in the Confucian heritage that knowledge should flow freely (and that does not support the view that an individual can generate or own IPR), and in the Legalist tradition "in which rulers established the law" (Bosworth \& Yang, 2000: 455). Thus, the law in China "is used to facilitate government industrial policy goals and secure discrete economic outcomes that might not otherwise emerge through purely market-driven transactions" (Jannace \& Tiffany, 2019: 1393).
Such activities are especially pronounced in those sectors where technological prowess is considered 'strategic.' At unprecedented speed and scale (Lewin, Kennedy, \& Murmann, 2016), China has been upgrading its technological capabilities through a variety of corporate governance and investment policy experiments with the explicit goal of joining the ranks of top innovation nations' (Zhou et al., 2016). It is worth noting that China has effectively created a new form of market capitalism and adopted a panoply of explicit probusiness policies (Coase \& Wang, 2012), some of which have been highly effective. However, China's policies also continue to enable the nonrespect of IPRs coupled with asymmetric regulations for many foreign investors in China (Brander, Cui, \& Vertinsky, 2017; Pagnattaro, 2012).

Even after joining the WTO, and despite recent changes China has made to the judicial enforcement of IPRs (Prud'homme, 2019), the Chinese government continues to support the acquisition of technology from abroad, either by purchase or by non-market means (Brander et al., 2017; Pillsbury, 2015; Wei \& Davis, 2018). It has been suggested that China (and Russia) have been engaging in systemic cyber-enabled economic and industrial surveillance (Hannas, Mulvenon, \& Puglisi, 2013). This is in addition to China requiring foreign entities to transfer sensitive IPR and technological know-how through joint venture agreements (Branstetter, 2018; Wernau, 2019), a practice that had been long studied by IB researchers in the context of technology-poor nations (Hennart, 1989). Furthermore, Wong and Dou (2017) have argued that China is now affecting more forcefully the workplace of foreign companies by requiring stronger presence and a more active role of Chinese Communist Party (CCP) nuclei to monitor technological activities, among others.

While some equate China's present behavior to the 19th-century violations of IPR by the United States (Peng, Ahlstrom, Carraher, \& Shi, 2017), the most critical voices have argued that the tools deployed reach further than mere protectionism. As Jannace and Tiffany (2019: 1394) see it: "Chinese law ... is protean in nature and tends to conform not to deeply grounded and transparent principles but rather to the exigencies of the moment as understood and interpreted by the CCP." With respect to business conduct, some have even raised the question as to whether coercion is now a norm for Chinese economic statecraft (Feigenbaum, 2017). Of course, the realism school 
of thought suggests that exerting coercive power is how hegemonic status is gained (and maintained), perhaps irrespective of the hegemon involved (Witt, 2019). For example, Rugman and Verbeke (1989) observed 30 years ago that various forces in the United States were strongly advocating in favor of strategic trade policies, even though this country's administrative heritage would have made effective implementation of such policies highly unlikely. It could be argued that at present: "having formerly been a rule-taker, China is increasingly becoming a rule-maker, or at least a rule-shaper" of the new global order (De Graaff \& Van Apeldoorn, 2018: 118, italics in the original), but its policy intent is going far beyond conventional strategic policy intervention. Here, we observe the beginning of what some refer to as a 'new cold war' (Kaplan, 2019) between the United States and China. Some have gone even further, suggesting that "the defining question about global order is whether China and the US can escape Thucydides's Trap" $^{\prime \prime}$ (Allison, 2017: xvii).

China's rapid growth, its hybrid economic structure, and its arguably opportunistic approach to norms and rules that guide international commerce, have created both tensions among existing power constellations and revealed an alternative model. The model that China has developed may not be fully replicable, but it does offer an alternative lens on how to spur growth in developing nations (especially those of the autocratic type), and perhaps offers a credible path towards becoming a hegemon. Amsden (2001: 292) argues that developing countries have "the advantage of being able to choose among 'the rest' for a mentor." In fact, many agree that the Washington Consensus model (Williamson, 1993) is ebbing, while the model China has developed is advancing (McKinnon, 2010). Dirlik (2007: 20) goes even further, noting that "[a] century of revolutionary socialist search for autonomy, bolstered by recent economic success, qualifies the P.R.C. eminently to provide leadership in the formation of an alternative global order." By examining China's influence in Africa, McKinnon (2010) concluded that developing countries are more likely to emulate China's economic regime than follow the Washington Consensus.

The reaction of the IB scholarly community and policy makers is barely perceptible at present, with some exceptions. For example, the President of the Federation of German Industries, Dieter Kempf, has called for novel responses by the European Union (EU) and Germany due to “[t]he People's Republic
... establishing its own political, economic, and social model" (BDI, 2019b). The U.S. intelligence agencies recently issued the warning that "China's economic aggression now threatens ... the global economy as a whole" (White House Office of Trade and Manufacturing Policy, 2018: 1). Few scholars have joined the call to study these developments more seriously as academic subject matter (e.g., Ozawa, 2019; Witt, 2019).

The main reason for the lack of coordinated action to study (or respond to) these developments is perhaps that not everyone agrees an erosion of the global governance system is occurring. It could reasonably be argued that the One Belt-One Road initiative (see infra), the establishment of the Asian Infrastructure Investment Bank (AIIB) in 2016 to support economic and social outcomes in Asia, China's aggressive investment strategy in Africa, and state-backed and government-imposed controls and mechanisms are in fact China's way of 'shaping the rules' by creating parallel institutions to the existing ones. ${ }^{10}$ In fact, many individuals and nations seem to welcome the new global realities and changing posture of international commerce and influence. For example, Etzioni highlighted 15 years ago that:

Both the end-of-history and the clash-of-civilizations arguments approach the non-Western parts of the world as if they have little, if anything, to offer to the conception of a good society-at least to its political and economic designor to the evolving new global architecture (Etzioni, 2004: 26).

This sentiment is echoed by Kaplinsky (2013) who has suggested that China's growing presence in sub-Saharan Africa can facilitate Africa's transition to a more sustainable and more inclusive and equalized growth path. He attributes this to China's role in becoming a source of low-cost consumer and capital goods (appropriate for conditions of low-income economies) as well as creating new market opportunities and GVCs for small-scale producers in those economies. The recent work by Herrero and Xu (2019) examined media sources to assess public perceptions of China's Belt and Road initiative in different countries and regions around the world, and found that Central Asia and subSaharan Africa exhibit very positive coverage and attitudes towards this initiative. Furthermore, China enjoys the support of much of Southern Africa in many international forums (Taylor, 2007). The findings of the 2014/2015 survey by AfroBarometer $^{11}$ confirm China's important 
economic and political role in Africa and generally portray its influence as beneficial.

Despite, and perhaps because of, differing perceptions of China's new role in shaping the world economy, it is of utmost importance for IB scholars and practitioners to understand the implications of China's ability to not only move from the 'periphery' to the 'core,' but to disrupt the existing norms, values and the commonly understood rule-of-law. This reshaping will alter the structure of the global economic system along the lines of China's own economic model and its own 'rules of the game,' and may pave the way for other peripheral economies to emulate China's behavior (or even invent their own models or path to hegemony). In our view, this presents one of the "grand challenges" (Buckley, Doh, \& Benischke, 2017) that future IB scholarship should address.

Indeed, China may not be the only country involved in reshaping of the future global landscape. In 2014, India also launched its own 'Make in India' ${ }^{\prime 2}$ plan that is part of larger nationbuilding initiative and is targeting 25 sectors of the economy with the goal of transforming India into a global hub for manufacturing and design. In addition, Ozawa (2019: 190) has noted that "the progressive, multilateralism-ruled global ecosystem has brought about harm to its parts unevenly, especially the working class of the advanced world in general and of the United States in particular." Negative distributional effects in the country that has benefited most from the existing world economic order, are now giving rise to "America First" anti-globalism, protectionist policy by the current United States administration, adding additional concerns about the future landscape of IB (Meyer, 2017).

\section{New Forms of Strategic Trade and Investment}

The global financial crisis of 2007-2008 represented a profound climacteric, and has been a catalyst for the erosion of the prevailing rule-based system of international commerce. It encouraged the increasing "pressure exercised by the Periphery on the Center" (Mathews, 2006: 6), challenging the role of institutions ${ }^{13}$ that have underpinned the global commerce system thus far and the competitive advantage of companies that have relied on these institutions to support their modus operandi. It also revealed some weaknesses of deploying traditionally conceptualized FSAs and DCs within environments that operate based on different sets of rules and unorthodox economic models. As a result, we observe that the profit margins of many MNEs outside their home (core) markets are eroding (The Economist, 2017) and that global trade and foreign direct investment (FDI) levels exhibit pronounced downward trends (Witt, 2019). At the same time, China is emerging as the major source of outward FDI flows among the countries from the emerging markets (or periphery) to such an extent that it has significantly narrowed the gap between the inward and outward FDI flows (OECD, 2017).

Narula and Dunning (2000) specify two main categories of FDI motives for MNEs: (1) assetexploiting, which includes pursuit of natural resources and new markets, and restructuring of existing foreign production, and (2) asset-augmenting, which is primarily centered on seeking new strategic assets, whether for new knowledge, technological, or managerial capabilities (Meyer, 2015). For example, Buckley, Munjal, Enderwick and Forsans (2016: 994) found that Indian MNEs augment their marketing and technological capabilities by acquiring companies abroad, and support the view that some firms "develop bundling skills at home that can enable them to exploit foreignlocated assets by internalization and cooperation."

However, China's unique combination of market size and accelerated growth, particular emphasis on tapping into advanced innovation and technology development through outward FDI activities, and the distinctive government's role in systematically drawing upon its bargaining power to support technological upgrading, depart from traditional theoretical frameworks and empirical findings on FDI motivations and the internationalization process more generally. China's FDI policies provide the platform that facilitates Chinese firms' international expansion trajectories (Wei, Clegg, \& Ma, 2015) with the goal of capturing the fruits of innovation and knowledge from foreign entities to serve nation-state objectives. The pursuit of nationstate objectives is especially pronounced in the case of state-owned enterprise (SOEs) that China is increasingly mobilizing in its quest of technological upgrading (Du \& Zhang, 2018; Feng, 2019).

China's systematic and coordinated actions towards technological dominance are particularly noticeable with the announcement of One Belt-One Road $^{14}$ (also known as Belt and Road, or OBOR) initiative in 2013, followed by a launch of the Made in China 2025 (MIC 2025) plan in May 2015, and its associated, state-led techno-nationalist ${ }^{15}$ industrial policy that focuses on 'winning at all costs' to facilitate China's rise and dominance in key 
technological domains and enable its self-sufficiency. ${ }^{16}$ Relatedly, China's Thousand Talents Plan ${ }^{17}$ was designed to recruit global scientists and garner the United States expertise in technology and innovation, including military technology.

The rise of China and the pressure China is exerting should not be dismissed as déjà $v u$ or equated with the previous paths of Japan, Korea, Singapore, or Taiwan. Of course, one can argue that even the United States in the 19th century and Britain in the 17th century used predatory industrial policies (Chang, 2002). In earlier times, Korea, Taiwan, Singapore, and even Japan were playing by mercantilist rules too, thereby favoring domestic players and protecting infant industries. Yet, the impacts on the global economic system were absorbed with manageable disruption, because: (1) their economies were relatively small, and (2) these countries were themselves on a path evolving towards adopting a more liberal and open, rule-oflaw order. Neither condition applies to China, thus requiring IB scholars to think anew about the future IB landscape and the capabilities that MNEs need to develop for effectively navigating the new landscape. The Federation of German Industries has labeled the contemporary Chinese-like approach to IB as a new form of "systemic competition," which fuses firms and the state in ways that are uncommon (BDI, 2019a).

\section{THE ATTENDANT AMPLIFICATION OF "VUCA" CONDITIONS IN IB}

Irrespective of one's view of the role that China is playing on the global economic stage, or with regards to the nature of the structural reshaping of the global governance system, it is clear that today's IB environment is plagued with volatility, uncertainty, complexity, and ambiguity (VUCA) at an unprecedented scale (Bennett \& Lemoine, 2014; Schoemaker, Heaton, \& Teece, 2018; van Tulder, Verbeke \& Jankowska, 2020). Volatile environments are characterized by high frequency in change and high magnitude of change in the global system. The present reshaping of the world economic order in the form of de-globalization tendencies will have a significant impact on the ability of MNEs to adjust their resource portfolios and DCs to the new IB realities. This is especially significant in the global technological innovation domains. The erosion of the rule-of-law, with technological, geopolitical, and ideological shifts added, are multiplying uncertainties in the environment. Unpredictability of the global ecosystem's governance (Ozawa, 2019) is a manifestation of this uncertainty. ${ }^{18}$ Complexity is different from instability (volatility) and unpredictability (uncertainty), and also results in part from interdependencies due to multifaceted webs of relations woven in the IB environment that are both vexing and hard to navigate. For example, the MNEs' integration into both regional and global value chains (GVCs), which may now be moving towards decoupling (Rapoza, 2019), is an example of this augmented complexity. In ambiguous environments with integrated complex linkages, cause and effect are not well understood. The possible outcomes from the ongoing reshaping of the global economic order, and their impacts on the cross-border activities and prospects for MNEs to continue to profit from their innovations (Teece, 1986a) are highly ambiguous; so are the new forms of strategic trade and investment policies that run counter to the traditional conceptualizations.

For example, the conventional theories of the MNE typically suggest that firms undertaking FDI activities exploit ownership advantages and/or proprietary assets (Dunning, 2000; Hymer, 1976; Vernon, 1966), or bundles of CSAs and FSAs (Rugman \& Verbeke, 2003) when pursuing expansion strategies in host locations. However, outward FDI by MNEs from emerging economies shows that in some industries, the focus is more often than not on FSA acquisition (Wang, Hong, Kafouros, \& Wright, 2012), even if initial-stage entrepreneurial capabilities or extensive financial resources may be critical to the success of such acquisitions (whether in the form of assets or firms owning these assets).

While examples of FDI interventions are abundant (Krugman \& Obstfeld, 2000), Pack and Saggi (2006) argue that policy interventions and subsidies with respect to FDI are only justified if they create positive externalities. China has exhibited polymorphism, as to both the nature and the extent of its reach in promoting the interests of Chinese companies, and by extension its national interests, which are resulting in negative externalities for other players and nation states competing in the global economic landscape (Berry, 2017; European Commission, 2018a). Given the FDI policy initiatives in China, Buckley et al. (2018: 14) point to the need for a concerted effort to research "the full extent of the role that the Chinese state plays in China's OFDI, and how this might affect the downstream impact of OFDI within the host economy." 
The ability of foreign MNEs to leverage their traditional FSAs and DCs in such an environment is rapidly diminishing. In some cases, disengagement is being used as a possible strategic response. ${ }^{19}$

\section{Heightened Volatility, Augmented Uncertainty, Increased Complexity, and Intensified Ambiguity} The reshaping of the global economic order has cascading effects across several systems that are central to the functioning of the MNE. The new IB environmental conditions are characterized by amplified VUCA. This in turn is causing disruptions at the supra-national, national (both home and host countries), sub-national, and inter-firm/network levels (Ozawa, 2019). It also creates cascading disruptions, rippling through the institutional, market, and firm membranes (Lundan, 2018). The ability of MNEs to insulate themselves and their technological capabilities under such conditions is increasingly being limited.

Figure 1 is a stylized representation of the dependencies between different systems that will be impacted by the reshaping of global governance, and that may limit MNEs' ability to keep innovating (and profiting from innovation).

Creating and capturing value from innovation in the presence of cascading effects from systemic erosion of the rule-of-law in the prevailing global economic order, as described in Figure 1, will require new tools and new frameworks. Creating and capturing value through the use of new technology lies at the heart of the wealth of nations and, relatedly, military potential and national security (Rosenberg \& Birdzell, 1987). It has long been recognized that (efficient) international technology transfer is the symbol of an open international business regime, and helps provide the raison d'être for the MNE (Teece, 1986b). It is commonly understood that, absent state support, innovators need to capture value from their innovations in order to keep innovating. As Thomas Edison once put it, the only reason to make a profit, is to be able to keep innovating (Teece, 2018a), with the goal of sharing in the attendant prosperity.

In early investigations of national policies for technological innovation, development and adoption, Ostry \& Nelson (2000) suggested that the world had reached the stage of techno-nationalism, where states (in those days Japan and the United States) wished to have their own enterprises as market leaders in high-technology sectors. In essence, techno-nationalism assumes that nations are units that innovate, facilitate, and fund $R \& D$ and cultures of innovation, and that they use and diffuse those innovations and technologies to further national goals (Edgerton, 2007). It further

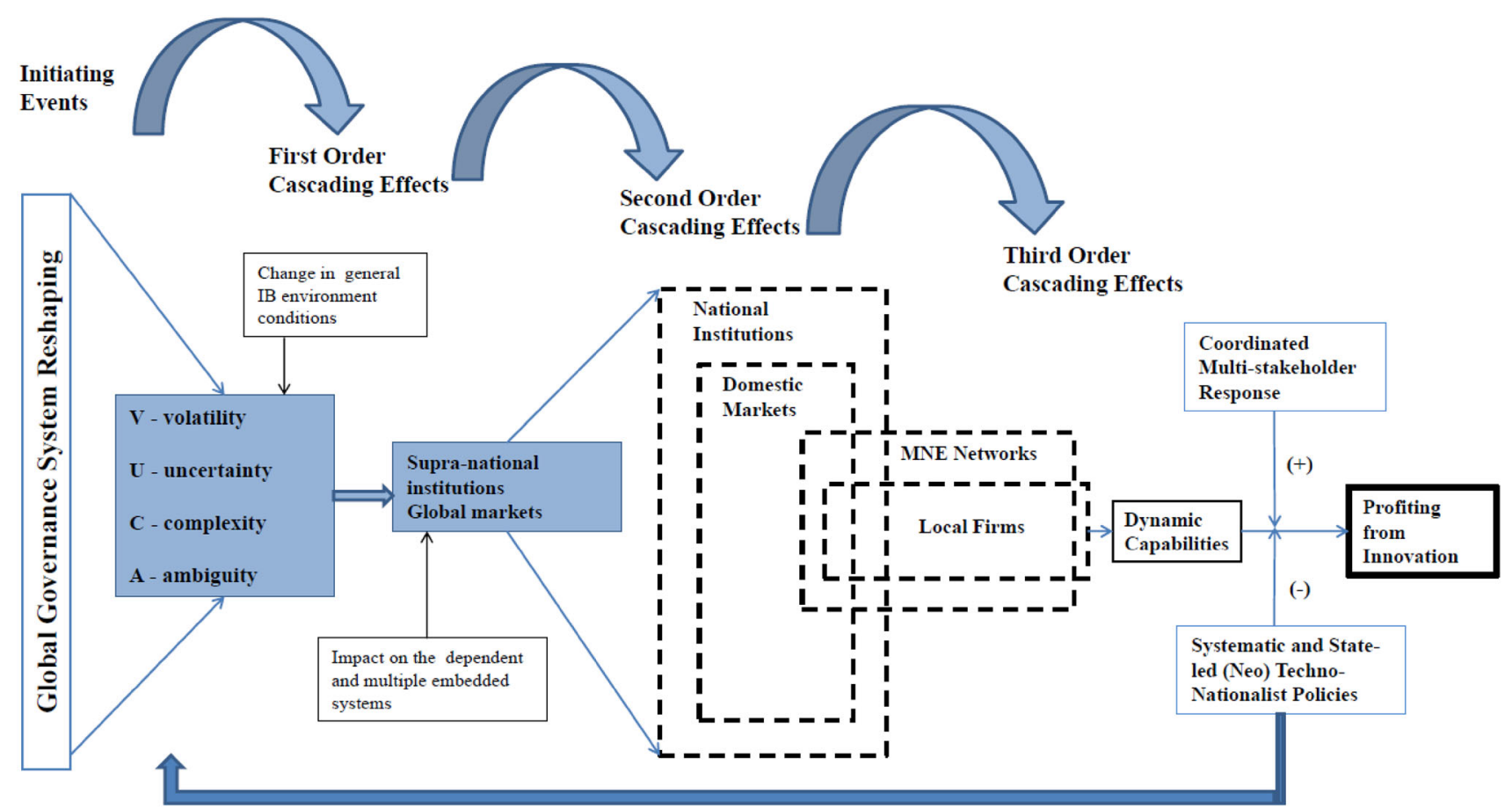

Figure 1 Cascading impacts of global governance system reshaping. 
implies that "the things a nation uses derive from its own innovations, or at the very least that innovating nations have early leads in the technologies they innovate" (Edgerton, 2007: 8). These assumptions do not hold in a global innovation system, which reflects much more a non-zero-sum situation, where one nation's wealth increases that of others. However, China's approach to capturing foreign innovations to further hegemonic goals of technological leadership is rapidly reintroducing techno-nationalism, albeit with a new emphasis, as an initiating set of events, creating first-order cascading effects, as illustrated in Figure 1.

The implicit assumption of techno-nationalism ${ }^{20}$ is that states protect the development of their technological capacities. When, however, states intervene by leveraging the opportunities within the international economic system (e.g., by dishonestly acquiring foreign intellectual property), to generate disproportionate gains from this system to serve their own economic and security interests, this resembles what some call (neo) techno-nationalism (Shim \& Shin, 2016; Suttmeier, Yao, \& Tan, 2004) and innovation mercantilism (Ezell, 2011; Nager, 2016). China has been developing a systematic and coordinated approach of institutional, market, and bargaining strategies to shape its global technological leadership (Higgins, 2015), and bring the benefits back home for its domestic players. Specifically, China has developed a state-directed approach that leverages national resources and regulatory systems to gain access to foreign-developed technology in key strategic areas. By focusing primarily on state-led interventionist policies to acquire technology advances that originate in other countries, thereby supporting its national objectives, China has moved beyond traditional conceptualizations of techno-nationalism.

In a recent policy brief, Branstetter (2018: 1) suggests that: "a broad range of experts and market observers agree that China has repeatedly forced foreign multinational corporations (MNCs) to transfer technology to indigenous firms as a condition for market access and that China has persistently failed to protect the intellectual property of foreign firms doing business in China." Branstetter (2018: 1) further claims that the United States' complaints in this regard are now being joined by "traditional European and Asian allies and trading partners." Support for his proposition comes from the Director-General for Trade of the European Commission, who noted on June 1st, 2018 that:
European companies coming to China are forced to grant ownership or usage rights of their technology to domestic Chinese entities and are deprived of the ability to freely negotiate market-based terms in technology transfer agreements. This is at odds with the basic rights that companies should be enjoying under the WTO rules and disciplines, in particular under the Agreement on Trade-Related Aspects of Intellectual Property Rights (TRIPS Agreement) (European Commission, 2018b).

International economists have recognized in formal models (e.g., Branstetter \& Saggi, 2011) that forced technology transfer could cause MNEs to alter their investment decisions and slow down innovation in the global economy, even if such innovation is advanced in one country. The magnitude and the types of strategic trade (protectionist) policies some countries are using are difficult to justify and are mostly inconsistent with existing FDI frameworks and theories. In fact, Verbeke et al. (2018: 1110) recently issued a warning to the IB community, stating that "national regimes thriving on the "forced sharing" of intellectual property by foreign companies in return for market access, may well represent the single most important threat to further corporate and macro-level globalization."

The effective limitation or even denial of access, or threat of denial of market access to foreign companies, hardly makes technology transfer activity of MNEs in China a 'voluntary undertaking.' This strategy was noted by Teece (1986a: 303): "In regimes of weak appropriability, governments can move to shift the distribution of the gains from innovation away from foreign innovators and towards domestic firms by denying innovators ownership of specialized assets." The implication of weak appropriability regimes, such as those observed in China, is that MNEs must try to develop alternative mechanisms (i.e., firm-specific value appropriation capabilities) and enhanced DCs in order to profit from their innovations (Lampert, Kim, Hubbard, Roy, \& Leckie, 2018; Teece, 1986a).

China's approach emphasizes four distinct steps in acquiring foreign technology: Introducing, Digesting, Absorbing, and Re-Innovating (IDAR). ${ }^{21}$ To foster IDAR objectives, the access to and acquisition of foreign technology for the benefit of Chinese firms (and Chinese national objectives) is explicitly included. ${ }^{22}$ For example, the recent report illustrates how technology transfer to Chinese competitors has enabled open access to critical knowledge assets arising from the United States innovations (Brown \& Singh, 2018). Similarly, van der Putten (2017) has examined Chinese FDI in the Netherlands and found that the main objective of most 
Chinese FDI (made primarily by SOEs) was not to gain access to the Dutch or the EU market. Instead, the main goal was to access advanced technology and established global innovation networks. What makes MIC 2025 a potential turning point in the reshaping of global governance is that it does not call for long-term cooperation, but for "self-sufficiency" through technology substitution and global leadership in strategic, high-tech industries. A European Commission strategic outlook paper on EU-China relations has indeed described China as an "economic competitor in pursuit of technological leadership, and a systemic rival" (European Commission, 2019: 1).

By playing by a different set of rules, China is affecting the viability of the existing global innovation ecosystem, requiring that other ecosystem partners change their strategy, i.e., leading to second order cascading events as suggested in Figure 1. Because of China's ambitions as a hegemon, this is not just an economic and business issue. It is a national security issue too, as the United States and the European Union are now starting to realize. In 2016, China established the 'military-civilian fusion' (MCF) fund to support and fund overseas acquisitions and projects deemed key to national and military interests. The Chinese People's Liberation Army (PLA) international research collaborations are aimed at accessing emerging and dual-use technologies. Foreign universities are often (albeit unintentionally) allies in China's (neo) techno-nationalist strategies (Joske, 2018). Specifically, PLA's activities and the objectives of its overseas research collaborations have been described as "[p]icking flowers in foreign lands to make honey in China" (quoted in Joske, 2018: $3)$.

\section{THE DIFFERENTIAL IMPACT ON STRATEGIC AND NON-STRATEGIC INDUSTRIES}

The reshaping of the world economic order, as described above, relates in particular to the 'industries of the future' or 'strategic industries' that are identified not just in China's MIC 2025 plan, but also in Germany's Industry $4.0^{23}$ plan. In the late 20th century, the semiconductor, computer, biotechnology, and civilian aircraft industries were commonly regarded as 'strategic.' Today, they are likely to also include artificial intelligence, advanced manufacturing, quantum information science, and 5G. However, in popular discussions of the topic, the delineating aspects of a strategic industry are rarely identified. It is important to define some dimensions of 'strategic' industries, as these are particularly vulnerable in the face of the ongoing reshaping of the world economic order and resulting VUCA conditions.

\section{What Are 'Strategic' Industries and Why Do They Matter?}

A strategic industry provides social benefits beyond the magnitude of its direct value-added contribution. These social benefits include two classes of externalities-those due to spillovers from innovation and those stemming from locational synergies, suggesting that 'strategic' industries can be defined according to whether: (1) they are technologically progressive, and (2) they provide infrastructure to other firms in the same industry or in related industries (Teece, 1991). These externalities are often regionally concentrated and are not usually concomitant with the borders of the nation state. They can also be spread internationally through dense networks of alliances (Engel, 2015). For example, the semiconductor industry in California's Silicon Valley can be defined as a 'strategic' industry. The recent report suggests that China's strength in semiconductors is still relatively weak (compared to the United States) and that China is still highly dependent on foreign technology in what are now deemed foundational technologies (Zenglein \& Holzmann, 2019). In order to remedy these weaknesses, China is mobilizing a variety of novel techno-nationalist tools, which are directed at acquiring foreign innovations and technology. This magnifies the appropriability challenges associated with general-purpose technologies (GPTs) and enabling technologies that are core pillars of 'strategic' industries.

\section{General-Purpose Technologies, Enabling} Technologies, and the Appropriability Challenge As elaborated in Teece (2018a: 1369), generalpurpose technologies (GPTs) "have economy-wide effects, get even better over time, and spawn other innovations because invention in one triggers discoveries and creates opportunities elsewhere." For example, lasers or the Internet are considered GPTs. On the other hand, enabling technologies ${ }^{24}$ (e.g., nanotechnology) may not meet all of the criteria for GPTs, but are often disruptive and can not only drive technological change across many industries but can also have large societal implications (Wilson, Kannangara, Smith, Simmons, \& Raguse, 2002). The key characteristic of enabling 
technologies and GPTs is that they have large (positive) spillover effects, rendering profiting from innovation difficult and complex even under open, liberal economic system (Teece, 2018a).

Strategic industries that spawn enabling technologies and GPTs invite and often require investment incentives and/or subsidies from government. The key issue with China's MIC 2025 is therefore not so much that the Chinese government is willing to subsidize and support such industries, but that the size and scope of such activities goes far beyond the classical conceptualizations of industry subsidies or protection (Zenglein \& Holzmann, 2019). MIC 2025 foresees massive subsidies, incentives, and mandates that require Chinese firms participating in high-tech sectors such as green energy, aerospace, pharmaceuticals, autos, artificial intelligence, and their related and supporting industries, to gain a global market leadership position. Because 'strategic' industries (or the industries of the future) often underpin both economic and national security, the VUCA conditions will be dramatically amplified in those sectors. ${ }^{25}$ MIC 2025 on its own can be considered an initial trigger for the first-order cascading effects, as described in Figure 1.

\section{IMPLICATIONS OF VUCA FOR THEORIES OF THE MNE}

China's approach to acquiring technological innovations so as to achieve global leadership in various strategic industries will be interpreted by some as an admirable alternative to the Western-led global economic order, but it is not without consequences for the world economy as a whole and for IB theories and frameworks. One implication is that it may no longer be possible to use cost minimizing or profit maximizing, in a meaningful way, as the lynchpin of the theory of the MNE. ${ }^{26}$

To conceptualize the likely evolution of MNEs under extreme VUCA conditions, IB frameworks will need to evolve from deep roots in cost minimization/profit maximization traditions, to explicitly address capability building for evolutionary fitness. Such frameworks will allow for explicit consideration of political and industrial policy actions and changes in institutional environments throughout the value-creating and -capturing process. More specifically, firms will be engaged systematically in anticipating and responding to firstand second-order cascading effects, as shown in Figure 1, and they will be key actors in the third- order cascading effects, as they continuously recombine resources and adjust their micro-level governance to the exigencies of the first- and second-order cascading processes. The notion of evolutionary fitness is designed to capture the essence of a world order in which the success and failure of firms cannot be explained by simple, straightforward profit-seeking, whether in the short-term or long-term. This is not to say that financial performance does not matter. However, the theory of the MNE now requires anchoring in framework(s) that recognize the importance of capability development and upgrading, as well as the deployment of capabilities in environments where being attuned to the geopolitical process is paramount (Lundan \& Li, 2019; Luo, 2000; Teece, 2014). These new theories and frameworks will also need to be cognizant of both capability protection (or buffering) and new types of home- and hostcountry contingencies, as new first-order cascading events arise. What can now be observed is that emerging economies beyond China foster knowledge reservoirs of their MNEs by using the power of the nation state and state-backed institutions. ${ }^{27}$

\section{Dynamic Capabilities for Managing New IB Realities}

The DC approach (Teece 2007, 2014) is a lens that provides a starting point for examining how MNEs can deal with VUCA conditions and achieve evolutionary fitness (Helfat et al., 2007; Schoemaker et al., 2018). The DC framework seeks to outline the structures, decision processes, and managerial actions that can support evolutionary fitness in a variety of contextual circumstances. As noted elsewhere (Teece, 2018b), DCs are the essence of a workable ecosystem theory, and can provide insight into: (1) the likelihood of achieving evolutionary fitness and (2) how to achieve it through co-evolution with stakeholders and environments (Pitelis \& Teece, 2010).

The recent macro-level developments illustrated in the sections above are making it more difficult for MNEs to achieve evolutionary (or ecological) fitness because foundational and stabilizing components of the global economic order are being challenged to their core. It could be argued that (neo) techno-nationalist strategies as adopted by China, possibly to be emulated by several other countries, are ultimately not very different in impact on MNEs from past world wars and major commercial conflicts among nations, but the difference lies in the nature of the innovations 
involved. Many of these innovations result from multi-billion dollar investments in technological development, and require large, geographically diverse markets to recoup these investments. Some scholars (Lessard et al., 2016; Luo, 2000; Teece, 2014) have made a strong case for the value of DCs in MNEs in general, and in the presence of deep uncertainties in particular (Teece, Peteraf, \& Leih, 2016). However, these earlier treatments did not consider how MNEs can profit from their own, large-scale investments in innovation, in an environment with deep market distortions because of government policies systematically eroding rule-oflaw governance. Thus, DCs alone at the enterprise level may not be sufficient to achieve evolutionary fitness, aligned with the macro-level. Coordinated, multi-stakeholder (or innovation ecosystem) responses may be required, as suggested in Figure 1.

The DC approach emphasizes "the firm's ability to integrate, build, and reconfigure internal and external competencies to address rapidly changing environments" (Teece, Pisano, \& Shuen, 1997; 516). Furthermore, the DC framework (Teece, 2007) emphasizes three clusters of entrepreneurial activities: (1) sensing opportunities (and threats), (2) seizing (and neutralizing) them, and (3) transforming the internal systems, culture, and business models to address the external changes. These three clusters of capacities provide both the starting point and the infrastructure for developing novel responses to VUCA characteristics of the new global economic order. To the extent that they are nonlocation bound, such capabilities are dynamic in nature and can indeed support evolutionary fitness (Narula \& Verbeke, 2015). In fact, Narula and Verbeke (2015) explain how contemporary internalization theory both implies and anticipates the entrepreneurial orchestration of resources and capabilities embedded in the DC approach. Building on these insights, Matysiak, Rugman, \& Bausch (2018: 244) highlight that: "the purpose of MNEs' sensing, seizing, and transforming is to achieve (ever new) resource-capability recombinations that confer competitive advantages in the form of nonlocation-bound FSAs, CSAs, and location-bound FSAs in dynamic industry and country environments."

The DC framework was originally developed to help understand the requisite upgrading of FSAs in regimes of rapid technological change (Teece et al., 1997). More generally, DCs thinking helps firms respond to volatility, uncertainties, complexities, and ambiguities stemming from technological change, changes in consumer preferences and behaviors, or changes induced by government policies (Teece et al., 2016). As such, DCs enable MNEs to adapt to the changing conditions in their external environments by helping them "create new markets and expand old ones" (Teece 2014: 12). Accordingly, the DCs approach is a relevant framework to study how MNEs address extreme VUCA conditions in their international environment. Specifically, the framework:

Provides the tissue and the logic to link disparate economic, organizational, managerial, and psychological studies of human capital, entrepreneurship, and cognition. It can do so because of its heterodox and interdisciplinary foundations. It embraces the core business disciplines, such as organizational behavior, corporate strategy, and the resource-based view of the firm, but also draws on numerous other sources, including sociology and behavioral psychology. It also draws on sub-disciplines of economics; the economics of innovation, evolutionary economics, transaction cost economics, and behavioral economics are all within its ambit. This eclecticism makes dynamic capabilities an overarching framework within which studies of firm behavior from a variety of perspectives can coexist under the broad umbrella of inquiry into how firms manage internal and external resources to build sustainable competitive advantages under deep uncertainty. (Teece 2016: 213)

The main goal of the DC framework is not cost efficiency or profit maximization per se, but evolutionary fitness, which is precisely what the reshaping of the global economic order, with its three levels of cascading, as shown in Figure 1, requires from MNEs. Here, DC thinking provides a starting point to examine success factors that undergird MNEs' trajectories when operating in structurally different host locations, including those dominated by technology-seeking state actors.

The 'acid test' for MNEs' evolutionary fitness in strategic sectors is whether they can protect their IP and other core proprietary assets, or at least minimize the leakage of such, in the new IB landscape (Teece, 2014; Verbeke, 2013). Obviously, the magnitude of the problem depends on how 'strategic' the industry that the MNE operates in, is to the national interests of its home country, and to the aspirations of host countries such as China aiming to upgrade their technological capacities without reliance on conventional norms and rules in the realm of IPR protection.

Some have suggested as a potential solution, the 'zooming in and out' across subnational and supranational boundaries to organize global value chain activities in the presence of VUCA conditions (Mudambi, Li, Ma, Makino, Qian, \& Boschma, 2018). In practical terms, this may imply spreading 
value chain activities across several countries, each with only partial access to the firm's overall technological reservoir, much in line with Gooris \& Peeters (2016). Managing for knowledge buffering across fragmented institutional environments places a great weight on the orchestration capabilities and leadership skills of the MNE's top managers (Pitelis and Teece, 2018). The requirements for such capabilities increase exponentially with higher embeddedness in multiple locations and institutional contexts. Each embeddedness layer is associated with a different set of actors and corresponding knowledge buffering challenges that MNEs must address effectively in order to create and appropriate value (Meyer, Mudambi, \& Narula, 2011). MNEs also need to manage different layers of internal embeddedness (Asakawa, Park, Song, \& Kim, 2018; Zollo, Bettinazzi, Neumann, \& Snoeren, 2016), whereby internalization per se may not guarantee protection from (neo) techno-nationalism, since some employees may ultimately prove more loyal to their nation state than to the firm. In fact, the findings of the study conducted by Liu and colleagues (2010) suggest an important role for human mobility in facilitating the international flows of knowledge and technology from technologically leading countries (i.e., developed nations) to followers (i.e., emerging economies). Thus, MNEs increasingly need to operate as differentiated networks, with the relevant differentiation at least partly guided by the VUCA conditions resulting from neo techno-protectionism, and the related knowledge buffering requirements. MNEs need to protect their IP in broader ecosystems with multiple linkages and boundary-spanning activities. This will require specialized collaborative capabilities for managing complex constellations of boundaryspanning, inter-firm relationships (Petricevic \& Verbeke, 2019). The DCs required for designing and shaping networks of multiple stakeholder relationships (Rowley, 1997) and across multiple embeddedness dimensions (Ferraris, 2014) thus become especially hard to achieve with amplified VUCA (Helfat et al., 2007: 7), as suggested by the third-order cascading effects in Figure 1.

\section{Can Dynamic Capabilities Lead to Renaissance of the MNE?}

MNEs do not have the power of nation states seeking to access and acquire their intellectual property, but these firms' DCs can individually and collectively shape the business environment both at home and abroad (Cantwell et al., 2010;
Teece, 2007, 2014; Pitelis \& Teece, 2010). In fact, in VUCA environments, this aspect of DCs, i.e., the potential of shaping, rather than simply adapting to the reshaped external environment, may be critical to creating and appropriating value, especially when facing (neo) techno-protectionist state actors.

While traditional views of DCs mainly emphasize adaptation to the external environment (Zollo \& Winter, 2002) and firm-level evolutionary fitness (Helfat et al., 2007), today's realities require a much stronger emphasis on capability building and shaping of the environment through co-evolution with external actors (Parente, Rong, Geleilate, \& Misate, 2019; Schreyögg \& Kliesch-Eberl, 2007; Teece, 2018b).

Specifically, sensing (and sense-making) requires filtering mechanisms that transcend market intelligence in the IB context, and involve spanning multiple external and internal boundaries. Sensing capabilities are particularly centered on the process of identifying new opportunities and threats. Here, the existing IB literature has mainly focused on identifying needs for co-locating activities to respond adequately to new market opportunities (Narula \& Santangelo, 2009), but more attention now needs to be paid, when sensing market opportunities, to what is almost the mirror image of co-location, namely contemplating the need to locate activities embodying narrow knowledge bundles and narrow innovation-related activities to avoid unwanted external appropriation by (neo) techno-nationalism driven actors. Making proper trade-offs when sensing a business opportunity, between the need to co-locate value chain activities as a possible response to the opportunity, and the imperative of IPR protection, will require stronger consideration of managerial cognition and cognitive frames and attention in capability development (Eggers \& Kaplan, 2013).

Seizing capacities require rapid and coordinated responses, and they focus on mobilizing and appropriately bundling CSAs and FSAs to respond to identified opportunities, or to neutralize threats. In this aspect too, the existing literature has tended to focus mainly on opportunities to be acted upon, rather than on building or upgrading capacities to neutralize potential threats. In particular, seizing must now focus on concrete buffering approaches to avoid unwanted dissipation of proprietary technologies, and the firm's signature managerial practices. One key aspect here is the development of strong relational capabilities, for example when managing GVCs (Kano, 2018). This will be 
especially relevant when managing joint ventures or R\&D-based collaborative relationships. In fact, Adams (1980) early on suggested that protecting the organization and buffering it from external threats and pressures is one of the critical foci of attention when firms engage in boundary-spanning activities. Ryu, McCann, \& Reuer (2018) specifically investigated risks of knowledge losses resulting from 'partner-rival' geographic co-location, and found that effective, alliance governance design choices were important, e.g., by narrowing the scope and reducing the task interdependencies within the alliance. While the extant literature has focused mainly on learning and on the transfer of knowledge and skills, the new IB realities will require a stronger focus on developing mechanisms for buffering key technological capabilities, not only as a function of micro-level frailties, but especially to protect against the vagaries of (neo) techno-nationalist policies.

Transformational capacities of the firm in the traditional DC approach have again typically addressed organizing for well-defined opportunities to achieve novel resource combinations. However, the third-order cascading processes in Figure 1 require the MNE to achieve novel resource alignments, both internally and with other partners, whereby the default assumption must be that in some host-country contexts proprietary knowledge will be at high risk of unwanted dissipation. As a result, 'global' organizational approaches to exploiting, recombining, and augmenting technology are now a non-starter, and must be replaced by a 'bifurcated world' approach. The balancing act between operating simultaneously in rule-of-law environments, and in a possibly increasing number of locations where the rule-of-rulers prevails, because of (neo) techno-nationalism, as far as respect for IPRs is concerned, reflects extreme VUCA challenges, with the firm 'teetering on the edge of chaos' (Mycek, 1999). At the same time, success at such a balancing act means that the MNE will at least partly be able to fight off unreasonable demands for access to its technology and can shape the contexts where it operates. ${ }^{28}$

\section{Individual Firm Actions}

With rule-of-law international commerce in retreat, sustained innovation, growth, and profitability is likely to require much stronger reliance on relational capabilities (Lorenzoni \& Lipparini, 1999), co-evolution with institutional environments (Cantwell et al., 2010), harnessing the power of networks and network orchestration (McDermott, Mudambi, \& Parente, 2013), and a more encompassing and interdependent, i.e., ecosystems view of DC development and deployment (Teece, 2018b). However, this may not be enough. New leadership skills will be necessary, with emphasis on political astuteness, improvisation, and orchestration abilities that simultaneously elevate both leader character and leader competences (Sturm, Vera, \& Crossan, 2017) as well as creative search and strategic sense-making (Pandza \& Thorpe, 2009). Careful calibration of knowledge protection and disclosure (Contractor, 2019), and enhanced strategic intelligence (Levine, Bernard, \& Nagel, 2017) will underpin these leadership skills, so as to operate successfully in the amplified VUCA environment. Specifically, firms' dynamic political management capabilities that can influence institutional processes will become increasingly relevant (Oliver \& Holzinger, 2008). If an MNE's partner is a state-owned enterprise (SOE), this is especially poignant (Haveman, Jia, Shi, \& Wang, 2017).

As suggested by the third-order cascading processes in Figure 1, MNEs will be required to harness the power of value-appropriation capabilities through innovative supply chain deployment and design of innovation activities, which will be both disaggregated and dispersed in such a way that makes it difficult for any one participant in the chain to replicate the technology or firm-specific capabilities. Very early on, Casson and associates (1986: 1) drew particular attention to the globalization of supply chains, noting that "[w]ithin many industries, production processes have become split into a larger number of separate activities, and this has, in turn, increased the number and variety of intermediate products within the production system." When technology misappropriation is a concern, Schotter and Teagarden (2014: 45) suggest, "physically separating manufacturing and $\mathrm{R} \& \mathrm{D}$ processes, disaggregating proprietary components and compartmentalizing critical know-how are essential for effective IP protection." Thus, careful attention should be given to global value chain governance (Gereffi, 2018; Gereffi, Humphrey, \& Sturgeon, 2005), and to segmenting geographically the activities included in parallel, supposed 'global' information transfer systems and 'global' innovation networks (GINs), thereby achieving requisite 'isolation levels' of critical information and innovation. For example, Lampert et al. (2018) discuss how in some cases 
IP components can be geographically distributed to make technology theft more difficult. Similarly, Gooris and Peeters (2016) studied 581 foreign service production units and found that fragmentation of business processes across different units (organizationally and/or geographically dispersed) offers an information protection mechanism in host locations with high misappropriation hazards.

While developed-country MNEs are still critical drivers of international innovation, the present role played by emerging economies in changing the global innovation landscape cannot be ignored. China is seen as a new key locus for innovation. Some have argued that this new posture might also present an opportunity from the reverse innovation perspective (von Zedtwitz, Corsi, Søberg, \& Frega, 2015). Given that each phase of innovation (from ideation to commercialization) can occur in any geographic location, von Zedtwitz et al. (2015) introduced a new typology of global innovation. They identified 16 different types of innovation flows between advanced and emerging countries, most of which are reverse innovation flows. This approach suggests that MNEs will likely need to develop and upgrade their CSAs and FSAs for managing and monitoring the portfolio of global (reverse) innovation flows and upgrading the ordinary and dynamic capabilities needed to appropriate value from complex relationships and networks.

The GINs perspective takes a non-linear approach toward re-organizing global innovation activities (Parrilli, Nadvi, \& Yeung, 2013) as it specifically addresses the "globally organized web of complex interactions between firms and non-firm organizations engaged in knowledge production related to and resulting in innovation" (Barnard \& Chaminade, 2011: 2). The GINs perspective aligns well with the ecosystem view of DCs, as it considers diverse sets of actors, the complexity of their intraand inter-firm linkages, and the multiplicity of geographical locations involved in innovation activities. Integrating the insights from the GVC and GIN literatures on how to design, navigate, monitor, and enforce IP protection within the intersecting GVCs and GINs, might prove helpful as the starting point for specific actions MNEs can take in re-tooling their competencies and upgrading of their DCs. A critical capability for managing the ever-evolving MNE network under VUCA conditions will be the firm-level regulation of the permeability of the collaborative membrane with respect to knowledge and IP flows. However, this will come at a cost. Greater dispersion of $\mathrm{MNE}$ innovation-related activities will place pressure on the available bandwidth and absorptive capacity, and may result in decreased innovation quality (Narula, 2014; Singh, 2008).

An additional strategic prong to strengthen DCs is to engage with an unexpected partner in reshaping the competitive dynamics, for example in China, where the MNE might choose a particular Chinese partner with the objective of creating competitive tensions. Chinese firms are very competitive and this might provide a useful strategy in some circumstances. Prospects in China are probably best for non-technology companies in nonstrategic sectors, such as agriculture, fashion, consumer goods, and even insurance. For example, Canada's largest insurance company Manulife continues to be optimistic about growth opportunities in China (and the Asia region), after more than 120 years of operations in China (Ligaya, 2019). For firms in any of the strategic sectors where China is pursuing breakthroughs, the outlook is more challenging. Firms in these sectors must be extremely vigilant, if they enter the Chinese market at all. Engagement by individual firms with the Chinese market, without adequate focus on the DCs related to knowledge buffering as outlined above, might bring short-term gains, but a long-term weakening of capabilities. Uncertainty alone is reducing FDI flows and driving disengagement and decoupling.

\section{Multi-Stakeholder Coordinated Actions}

Scholars have identified strategic benefits of building cooperative relationships between foreign entrants and a host-country's political, economic, and social stakeholders (Dorobantu, Heinisz, \& Nartey, 2017). Unfortunately, the fundamental problem faced by many MNEs (especially the U.S. ones) with respect to collective action against, e.g., the Chinese, state-led technology acquisition strategy, is the presence of anti-trust and competition policies: these prevent and sanction coordinated actions that could block transfers of critical technology to China. More restrained collective action that involves working with (international) industry associations to share intelligence and identify technology-buffering approaches remains a legal option. However, MNEs have found only limited means of redress in world forums, although disputes have now become sufficiently salient to move some MNE home countries to action. ${ }^{29}$ An effective policy response will require comprehensive efforts and both unilateral and multilateral cooperation between and among MNEs, their home 
governments, and other stakeholders, with MNEs potentially responsible for triggering the first-order cascading effects in Figure 1.

The combined power of the state and private enterprise in rule-of-law environments might prove very effective. Pack and Saggi (2006) find little evidence to support the role of industrial policies in correcting market failures in a traditional sense, but they do suggest that the time is ripe to consider a new type of industrial policy that focuses on negotiations with multinational firms. In fact, Sojli and Tham (2017) find that firms with shareholders that are large, active, and have extensive foreign political connections, benefit from these relations, both by creating positive short-run performance effects and by increasing firm value in the long-run.

As documented in extant research outside of the mainstream business and management literature (e.g., Chang, 2002; Weiss, 1997), the United States, many EU-member states, as well as Japan, have a long history of interventionist policies supporting the activities of their MNEs and infant (strategic) industries through preferential access to markets, tariffs, and the cross-subsidization of R\&D activities, thereby distorting the competitive landscape in favor of their own domestic 'champions.' Some have argued that one important positive outcome of such interventionist policies of the past was the accelerated diffusion of technology (Weiss, 1997). Others have suggested that developed countries are now "kicking away the ladder" that they themselves used in order to climb up to their current status and are only now exhibiting preferences for less intervention (Chang, 2002). Overall, most governments intervene to some extent to protect their national interests (Krugman \& Obstfeld, 2000; Ostry \& Nelson, 2000), but the extent to which they do and the means they use have differed significantly. ${ }^{30}$ As one example suggests:

\footnotetext{
Countries such as the US have hitherto attempted to deal with root causes of market failures by attempting to make markets more efficient, but only directly intervening on a reactive, case-by-case basis (for instance, in sectors which defence applications may exist). Countries such as France and Japan, on the other hand, have taken a more active, or direct role (see Nelson [ed.] 1993). Narula (2003: 264)
}

Here, the focus should be on changing what constitutes "the desirable, the practical, and the permissible" selective state intervention (Lall, 2004: 27) that might be appropriate for the new era of fragmented global governance. In 2013, the EU identified China's pressure for technology transfer amongst the chief barriers to investment there
(European Commission, 2013). As China is "poking at Europe's belly and finding it soft," the EU adopted a new China strategy in 2016, looking for more cooperation and coordination of positions among member states (The Economist, 2018a).

The new IB realities will require leveraging the power of the nation states where the rule-of-law prevails, and that of other stakeholders the firm engages with in its ecosystem, to develop and implement industrial policies bolstering innovation. Specifically, "the demand on governments' abilities as moderators and catalyzers in the innovation process will increase in order to release boosters and make synergetic effects realizable" (Weiss, 1997: 85). Such policies should support emerging business enterprises in strategic industries and those developing enabling technologies. This will, perhaps paradoxically, also trigger the need to widen the scope of non-market strategies that MNEs will need to develop and mobilize (Dorobantu, Kaul, \& Zelener, 2017). The first- and second-order cascading effects triggered by (neo) techno-nationalism would therefore not just lead to third-order, reactive cascading processes at the MNE level, as suggested by Figure 1, but MNEs would themselves become the initiators of counterpunching, first- and second-order cascading processes, emanating in rule-of-law countries.

\section{CONCLUSION}

Globalization in the post-WW II era, in the sense of increased economic exchange and the deepening of international economic linkages among nations, has been greatly facilitated by transparent and non-discriminatory rules at the macro-level, and the adherence to those rules by nation states and MNEs. This downward cascading has been complemented with an upward cascading motion, whereby the MNE has in turn been the main governance structure at the micro-level responsible for fuelling macro-level globalization and economic growth in the post-WWII period. The community of nations collectively established a reasonably open, transparent global economy with liberalized financial and information flows. Globalization has created substantial flows of capital and technology, and it has motivated many nation states once situated on the 'periphery' of the global economic system to use this system as a vehicle to guide their industrial development process. 
This global economic order is now being reshaped. The role of government interventions in designing novel 'latecomer' institutions and in taking short cuts for catching-up with global industrial development dynamics, has deep intellectual roots (Chang, 2002; Mathews, 2005). Traditional mercantilist approaches have been practiced since the 17th century, and were first codified in the form of the United States "catch up" industrial policy by Alexander Hamilton in his "Report on the Subject of Manufactures", presented to the United States Congress in 1791. During the 19th century, the United States also engaged in various forms of IPR violations (Peng et al., 2017). The evidence of government interventions by developed nations can also be found in recent history (Ezell, 2011).

However, countries that are now prioritizing industrial policies aimed at acquiring foreign technology and innovation, by deliberately eroding the rule-of-law, should not just receive a passive response. Nor should these countries governed by the rule-of-rulers be viewed as the equivalent of historical precedents and be expected to engage in self-correction over time, as some have suggested (Peng et al., 2017). These countries are practicing novel, systematic, and systemic mercantilist approaches, thereby triggering massive VUCA conditions for MNEs and large-scale cascading processes, as described in Figure 1. The dynamic capabilities (DC) framework suggests that MNEs should actively devise their own destiny, and should engage, where possible, in collective responses utilizing a multi-level, multi-national, and multi-stakeholder approach, thereby triggering 'their own' first-order cascading processes. Individual firm actions should be augmented with coordinated industry (or ecosystem) and state-level responses, both mini-laterally (e.g., Group of Twenty-G20 in the realm of economic cooperation, BRICS New Development Bank in the realm of alternative international financial institutions, etc.) and multi-laterally (e.g., the EU and its aim at developing an integrated industrial policy for its member countries that would promote a European "industrial renaissance").

The industrial policy interventions with their novel tools that we observe today are inconsistent with traditional theories on strategic trade and investment policies, and internationalization motives. The dynamics at play are not the conventional (temporary) sheltering of domestic markets against more advanced foreign rivals, through building up a domestic industry. The strategy is to acquire the most advanced IP of these foreign rivals by circumventing norms and rules on IP protection, and then to utilize this foreign-acquired knowledge to achieve global technological leadership. Such policies are eroding and fragmenting the global economic order based on the rule-of-law, and creating extreme VUCA conditions for both MNEs and nation states. Despite commonly accepted tendencies that "business abhors borders" (Horsman \& Marshall, 1994: 60), the MNE's ability to immunize itself from the resulting cascading effects, is a daunting challenge. New trade and investment barriers imposed by nation states that rely on the rule-of-law, can help shield MNEs from unwanted knowledge dissipation.

The global market is not "losing its taste for global business" as the editors of The Economist (2017: 18) have recently asserted. Rather, some nation states have developed the proclivity for undermining the commonly accepted rule-of-law, in unapologetic attempts to appropriate more of the benefits from commerce and innovation for their own national champions and special interests.

Many MNEs are uncomfortable operating in higher VUCA environments, and will consider divesting from nations imposing 'innovation-sharing' (as many are already doing). A DC approach, however, with its focus on achieving evolutionary fitness, provides a number of additional strategy options. These range from sophisticated technology buffering strategies to what could be a cornerstone of the new enlightenment, namely the initiating of cooperative action with rule-of-law abiding governments, and the co-designing of effective multi-stakeholder policies. Such policies should guarantee that the fruits of innovation in the global economy cannot be unduly acquired by (neo) techno-protectionist states. Here, the driver of individual MNEs' actions should not be the conventional 'profiting from innovation' target, but rather the insight that a rising tide will lift many boats, with IPR protection recognized as the global economic system's premier public good that logically deserves exceptional and impassioned collective action. Absence of such collective action, may pull an increasing number of countries towards pursuing simplistic tit-for-tat, (neo) techno-nationalist policies, which would be an unfortunate outcome as it would likely diminish the world's long-run technological innovation capacity in strategic sectors. 


\section{ACKNOWLEDGEMENTS}

We thank the Editor, Professor Rajneesh Narula, for very constructive and helpful guidance throughout the revision process, and two anonymous referees for their insightful comments. We also gratefully acknowledge discussions on the earlier versions of this paper and comments received from Paul Tiffany, Arie Lewin, Bruce Guile, Greg Linden, Michael Witt as well as participants at the 2019 New Enlightenment Conference in Edinburgh, Scotland.

\section{NOTES}

${ }^{1}$ Countries outside of the North Atlantic were classified as "the rest" and included China, India, Indonesia, South Korea, Malaysia, Taiwan, Thailand, Argentina, Brazil, Chile, Mexico, and Turkey (Amsden, 2001:1).

${ }^{2}$ Benito and Narula (2007) identified the 'core' circa 2007 to be consisting of the United States, Germany, France, UK, Belgium, the Netherlands, Japan, and Canada, while other nation states were identified as 'the rest' or 'periphery' or 'on the periphery of the periphery' based on the level of integration into the global economy (by volume and density of foreign direct investment (FDI) activity). Similar classifications can be found in the political economy literature, for example examining trade relations between North and South (cf. Dahi \& Demir, 2017). The countries of the North are usually defined as developed (or First World/center/core/metropolis) and include North America (except Mexico), Western Europe, Japan, Oceania, and Israel. The countries of the Emerging South are usually defined as developing (or Third World/less developed/peripheral) while the countries of the Rest of South have not reached the partially industrialized or developing status.

${ }^{3}$ By rule-of-law, we do not refer to a specific class of laws. We refer to a legal system that is supposed to be impartial as to how it treats individuals and organizations, and is applied equally to all parties (including foreign-owned or controlled actors), in a non-discriminatory and transparent fashion.

${ }^{4}$ The term "dragon multinationals" was introduced by Mathews (2002) in his book "Dragon multinationals: A new model of global growth" to describe firms internationalizing from the countries (e.g., Brazil, India, China, etc.) that originally occupied the periphery of the global system.
${ }^{5}$ National Science Foundation and National Science Board. Science and Engineering Indicators 2018 (NSB2018-1). Full Report available at https://www.nsf.gov/ statistics/2018/nsb20181/report. Accessed 10 July 2019.

${ }^{6}$ Classical liberalism as used here has at least three dimensions: economic freedom, liberty as the primary political value, and social freedom.

${ }^{7}$ The World Justice Project Rule of Law Index ${ }^{\circledR}$ measures how the rule-of-law is experienced and perceived by the general public in 126 countries and jurisdictions worldwide across eight factors: Constraints on Government Powers, Absence of Corruption, Open Government, Fundamental Rights, Order and Security, Regulatory Enforcement, Civil Justice, and Criminal Justice. Full report available at https://worldjusticeproject.org/ourwork/research-and-data/wjp-rule-law-index-2019. Accessed 5 July 2019.

${ }^{8}$ Ideas about the rule-of-law are central to Western legal and political thought since Aristotle distinguished between the rule-of-law and 'the rule of the individual.'

${ }^{9}$ Thucydides Trap refers to the phenomena of a rising power and an established dominant power almost always breaking into conflict. Allison (2017: $\mathrm{xx}$ ) notes that "[a]voiding Thucydides's Trap in this case [US-China] will require nothing else than bending the arc of history." For additional analyses see Allison (2017).

${ }^{10}$ China's vibrant ancient history, culture, literature, and writings furthermore illuminate important aspects of the norms and values that guide its conduct today (Pye \& Leites, 1982). For example, some argue that China has done a good job, following advice of Deng Xiaoping, of "hiding capacities and biding time" (Chen \& Wang, 2011: 198). The sinologist Schwartz early on suggested the need for sensitizing and analyzing the ongoing changes with respect to China "within the framework of a civilization in which modern Western premise of a total qualitative rupture with the 'traditional' past has not occurred" (Schwartz, 1985: 2).

${ }^{11}$ AfroBarometer. 2014/2105. AD122: China's growing presence in Africa wins largely positive popular reviews. https://afrobarometer.org/ publications/ad122-chinas-growing-presence-africawins-largely-positive-popular-reviews. Accessed 1 April 2019.

${ }^{12}$ Make in India. http://www.makeinindia.com/ about. Accessed 1 April 2019. 
${ }^{13}$ The pillars of the post-WWII international commerce system were: (1) The Bretton Woods system of monetary management and stability; (2) the GATT, established in 1948 to promote multilateralization of trade relations. It subsequently morphed into the WTO; and (3) the IMF and the World Bank, established inter alia to provide longterm financing for economic development. The United Nations Conference on Trade and Development (UNCTAD) was established in 1964 to stimulate trade, investment, and development opportunities for developing countries and help them integrate into the world economy.

${ }^{14}$ In 2016, this initiative was re-named as Silk Road Economic Belt and the 21st-century Maritime Silk Road, and it is presented as an infrastructure, energy, and transportation project aimed at linking China to 70 countries in Asia, Africa, Europe and Oceania.

${ }^{15}$ China's Technonationalism Toolbox: A Primer. (2018, March 18) U.S.-China Economic and Trade Review Commission. https://www.uscc.gov/sites/ default/files/Research/China\%27s\%

20Technonationalism.pdf. Accessed 1 September 2018.

${ }^{16}$ China's self-sufficiency attitude can be traced back to the perspective of Mao Zedong, Chairman of the Communist Party of China, which contrasts sharply with the philosophy characterizing open trading regimes that take their intellectual heritage from Adam Smith and David Ricardo.

${ }^{17}$ The Thousand Talents Plan. http://www. 1000plan.org/en/history.html. Accessed 1 September 2018.

${ }^{18}$ While Knight (1921: 259) defines uncertainty as a state where it "becomes impossible to classify instances objectively," Milliken (1987: 136) distinguishes three types of perceived environmental uncertainty, each referring to the imperfect understanding of environmental conditions: state uncertainty (not knowing how environmental components might change), effect uncertainty (not knowing to which extent environmental changes might affect the organization because it lacks sufficient knowledge of cause-effect relationships between components), and response uncertainty (not knowing which options might be available to react to environmental changes as well as to which consequences a certain response option might lead).

${ }^{19}$ Whereas MNEs invested with enthusiasm in China from the early 1990s on, wishing to take advantage of the growth of the Chinese economy, most MNEs have had a mixed experience. For example, Google had a well-documented, very poor experience. Other foreign MNEs have done remarkably well. For example, BMW apparently makes most of its profits in China (Boeriu, 2018). However, many firms are now re-evaluating their positions in-and capabilities for-operating in China. As a result, some MNEs are actively divesting noncore or underperforming assets, or exiting China entirely. According to the 2017 annual Chinese Business Climate Survey Report (issued by AmCham China in partnership with Bain and Company), nearly a quarter of respondents say they have recently moved or plan to move operations out of China. Companies which have exited Chinese operations include Adobe, Best Buy, Home Depot, L'Oreal, Mark \& Spencer, McDonald's, Nikon, Panasonic, Seagate, Sony, Tesco, and Uber, while several others are announcing that they will soon depart (e.g., Staples). Nearly half of the surveyed firms feel they are not treated fairly when operating in China, with the highest level of concern (59\%) in R\&D-intensive industries. Many U.S. small, entrepreneurial firms, once enchanted by economic prospects that China might offer, are also leaving (Areddy, 2018). China's investment in the United States is likewise declining.

${ }^{20}$ The term was first coined in 1987, by Robert Reich. It referred to the United States policies to protect technological breakthroughs from supposedly unfair exploitation by Japan. For a detailed discussion of this 'policy guidance', see Reich (1987) and Kennedy (2013).

${ }^{21}$ For a comprehensive report and detailed discussion, see the Office of the United States Trade Representative. Findings on the Investigation into China's Acts, Policies and Practices Related to Technology Transfer, Intellectual Property, and innovation Under Sect. 301 of the Trade Act of 1974. (22 March 2018). https://ustr.gov/sites/ default/files/Section\%20301\%20FINAL.PDF. Accessed 1 August 2018.

${ }^{22}$ IDAR Opinions $§ 7-9,11-12$ (cited in Ibid).

${ }^{23}$ Detailed information can be found at https:// www.plattform-i40.de/PI40/Navigation/EN/Home/ home.html.

${ }^{24}$ The European Commission identified six "key enabling technologies" that are non-software research fields (micro and nanoelectronics, nanotechnology, industrial biotechnology, advanced materials, photonics, and advanced 
manufacturing) that underpin innovation in products across many industries (Commission of the European Communities, 2009).

${ }^{25}$ However, some non-strategic sectors/industries are also likely to be implicated, albeit to a lesser degree. They are implicated because of collateral, second order cascading effects. For example, agriculture, not at all strategic in the sense described above, could be disrupted by retaliatory tariffs by China as the United States (and in the future possibly the EU) imposes its tariffs, in part to gain concessions on the IPR protection front. Nonstrategic industries may also become implicated when, as with cement and steel, China overinvests in certain industries and then attempts to gain market share globally.

${ }^{26}$ It may be possible to resurrect those as very long-term, multiple stage versions of supporting models, but none is to that extent developed at present.

${ }^{27}$ We thank an anonymous reviewer for making us articulate this point.

${ }^{28}$ Ordinary/operational capabilities should not be neglected. Supply chain decoupling well likely require re-adjusting of basic operations. "Best

\section{REFERENCES}

Adams, J. S. 1980. Interorganizational processes and organization boundary activities. In B. W. Staw \& L. L. Cummings (Eds.), Research in organizational behavior (Vol. 2, pp. 321-355). Greenwich, CT: JAI Press.

Allison, G. T. 2017. Destined for War: Can America and China Escape Thucydides's Trap? Boston and New York, NY: Houghton Mifflin Harcourt.

Altenburg, T., Schmitz, H., \& Stamm, A. 2008. Breakthrough? China's and India's transition from production to innovation. World Development, 36(2): 325-344.

Amsden, A. H. 2001. The rise of" the rest": Challenges to the west from late-industrializing economies. New York, NY: Oxford University Press.

Areddy, J. T. 2018. American entrepreneurs who flocked to China are heading home, disillusioned. Wall Street Journal Eastern Edition. December 8.

Asakawa, K., Park, Y., Song, J., \& Kim, S. J. 2018. Internal embeddedness, geographic distance, and global knowledge sourcing by overseas subsidiaries. Journal of International Business Studies, 49(6): 743-752.

Ash, T. 2018. China and the US: Trade war or cold war? Financial Times. December 6. Retrieved from: https://www. ft.com/content/fe6f63ea-f964-11e8-af46-2022a0b02a6c.

Asheim, B. T., \& Coenen, L. 2005. Knowledge bases and regional innovation systems: Comparing Nordic clusters. Research Policy, 34(8): 1173-1190.

Atkinson, R. D., \& Ezell, S. J. 2012. Innovation economics: The race for global advantage. New Haven, London: Yale University Press.

Barber, L., Foy, H., \& Barker, A. 2019. Vladimir Putin says liberalism has 'become obsolete'. Financial Times, June 27. Retrieved from: https:/www.ft.com/content/670039ec98f3-11e9-9573-ee5cbb98ed36. practices" will take on a new light when it is not the lowest cost source that one must access, but a secure source!

${ }^{29}$ In January 2018, a U.S. federal jury found the Chinese Sinovel Wind Group, the manufacturer of wind turbines, guilty of stealing wind mill technology and trade secrets from the U.S. supplier AMSC. In March 2018, the U.S. issued a formal report that placed pressure for technology transfer and belowmarket licensing terms at the head of a list of numerous complaints dominating the new trade dispute. Then in December 2018, the chief financial officer of telecom-equipment manufacturer Huawei Technologies Co. was arrested on suspicions of selling technology to Iran (The Economist, 2018b). Such judicial interventions are too rare and infrequent to provide a counter-balance to China's behavior.

${ }^{30}$ For a fairly critical commentary on how the United States has ignored its own history of mercantilism and interventionist policies, see Chang (2002). A comparative analysis of interventionist policies by the United States and European countries is offered in Weiss (1997).

Barnard, H., \& Chaminade, C. 2011. Global innovation networks: Towards a taxonomy. CIRCLE Paper, (2011/04). BDI. 2019a. China-Partner and Systemic Competitor. January 10. https://english.bdi.eu/publication/news/chinapartner-and-systemic-competitor/. Accessed 2 April 2019.

BDI. 2019b. Strengthen the European Union to better compete with China, January 10. https://english.bdi.eu/ article/news/strengthen-the-european-union-to-bettercompete-with-china/ Accessed 2 April 2019.

Beamish, P. W., \& Lupton, N. C. 2016. Cooperative strategies in international business and management: Reflections on the past 50 years and future directions. Journal of World Business, 51(1): 163-175.

Benito, G. R., \& Narula, R. 2007. States and firms on the periphery: the challenges of a globalizing world. Multinationals on the periphery (pp. 1-24). London, UK: Palgrave Macmillan.

Bennett, N., \& Lemoine, G. J. 2014. What a difference a word makes: Understanding threats to performance in a VUCA world. Business Horizons, 57(3): 311-317.

Berry, H. 2017. Managing valuable knowledge in weak IP protection countries. Journal of International Business Studies, 48(7): 787-807.

Bhaumik, S. K., Driffield, N., \& Zhou, Y. 2016. Country specific advantage, firm specific advantage and multinationality-Sources of competitive advantage in emerging markets: Evidence from the electronics industry in China. International Business Review, 25(1): 165-176.

Boeriu, H. 2018. MBW profit up 13\%, helped by China sales. BMWBlog. August 3. https://www.bmwblog.com/2017/08/ 03/bmw-profit-13-helped-china-sales/. Accessed 20 December 2018.

Bosworth, D., \& Yang, D. 2000. Intellectual property law, technology flow and licensing opportunities in the 
People's Republic of China. International Business Review, 9(4): 453-477.

Brander, J., Cui, V., \& Vertinsky, I. 2017. China and intellectual property rights: A challenge to the rule of law. Journal of International Business Studies, 48(7): 908-921.

Branstetter, L. 2018. China's forced technology transfer problem: And what to do about it. Peterson Institute for International Economics, Policy Brief, 18-13: 1-10.

Branstetter, L., \& Saggi, K. 2011. Intellectual property rights, foreign direct investment and industrial development. The Economic Journal, 121(555): 1161-1191.

Bremmer, I., \& Roubini, N. 2011. AG-zero world-the new economic club will produce conflict, not cooperation. Foreign Affairs, 90(2): 2-7.

Brown, M., \& Singh, P. 2018. China's technology transfer strategy. Defense Innovation Unit Experimental (DIUx). https://admin.govexec.com/media/diux_chinatechnology transferstudy_jan_2018_(1).pdf. Accessed 26 September 2018.

Buckley, P. J., Clegg, L. J., Voss, H., Cross, A. R., Liu, X., \& Zheng, P. 2018. A retrospective and agenda for future research on Chinese outward foreign direct investment. Journal of International Business Studies, 49(1): 4-23.

Buckley, P. J., Doh, J. P., \& Benischke, M. H. 2017. Towards a renaissance in international business research? Big questions, grand challenges, and the future of IB scholarship. Journal of International Business Studies, 48(9): 1045-1064.

Buckley, P. J., Munjal, S., Enderwick, P., \& Forsans, N. 2016. Cross-border acquisitions by Indian multinationals: Asset exploitation or asset augmentation? International Business Review, 24(4): 986-996.

Cano-Kollmann, M., Cantwell, J., Hannigan, T. J., Mudambi, R., \& Song, J. 2016. Knowledge connectivity: An agenda for innovation research in international business. Journal of International Business Studies, 47(3): 255-262.

Cantwell, J., Dunning, J. H., \& Lundan, S. M. 2010. An evolutionary approach to understanding international business activity: The co-evolution of MNEs and the institutional environment. Journal of International Business Studies, 41(4): 567-586.

Casson, M., \& Associates. 1986. Multinationals and world trade: Vertical integration and the division of labour in world industries. London, UK: Allen \& Unwin Ltd.

Chang, H. J. 2002. Kicking away the ladder: Development strategy in historical perspective. London: Anthem Press.

Chen, D., \& Wang, J. 2011. Lying low no more? China's new thinking on the Tao Guang Yang Hui strategy. China: An International Journal, 9(2): 195-216.

Chesbrough, H., Vanhaverbeke, W., \& West, J. (Eds.). 2006. Open innovation: Researching a new paradigm. New York, NY: Oxford University Press.

Coase, R., \& Wang, N. 2012. How China became capitalist. New York, NY: Palgrave Macmillan.

Commission of the European Communities. 2009. Communication from the Commission to the European Parliament, the Council, the European Economic and Social Committee and the Committee of the Regions-Preparing for our future: Developing a common strategy for key enabling technologies in the EU \{SEC(2009) 1257\}. https:// eur-lex.europa.eu/LexUriServ/LexUriServ.do?uri=COM: 2009:0512:FIN:EN:PDF

Contractor, F. J. 2019. Can a firm find the balance between openness and secrecy? Towards a theory of an optimum level of disclosure. Journal of International Business Studies, 50(2): 261-274.

Cuervo-Cazurra, A., \& Narula, R. 2015. A set of motives to unite them all? Revisiting the principles and typology of internationalization motives. Multinational Business Review, 23(1): 2-14.

Dahi, O. S., \& Demir, F. 2017. South-south and north-south economic exchanges: Does it matter who is exchanging what and with whom? Journal of Economic Surveys, 31(5): 1449-1486.

De Graaff, N., \& Van Apeldoorn, B. 2018. US-China relations and the liberal world order: Contending elites, colliding visions? International Affairs, 94(1): 113-131.

Dirlik, A. 2007. Global South: Predicament and promise. The Global South, 1(1): 12-23.

Dorobantu, S., Henisz, W. J., \& Nartey, L. 2017a. Not all sparks light a fire: Stakeholder and shareholder reactions to critical events in contested markets. Administrative Science Quarterly, 62(3): 561-597.

Dorobantu, S., Kaul, A., \& Zelner, B. 2017b. Nonmarket strategy research through the lens of new institutional economics: An integrative review and future directions. Strategic Management Journal, 38(1): 114-140.

Du, J., \& Zhang, Y. 2018. Does one belt one road initiative promote Chinese overseas direct investment? China Economic Review, 47: 189-205.

Dunning, J. H. 1958. American investment in British manufacturing industry. London, UK: Ruskin.

Dunning, J. H. 2000. The eclectic paradigm as an envelope for economic and business theories of MNE activity. International Business Review, 9(2): 163-190.

Edgerton, D. E. 2007. The contradictions of techno-nationalism and techno-globalism: A historical perspective. New Global Studies, 1(1): 1-32.

Eggers, J. P., \& Kaplan, S. 2013. Cognition and capabilities: A multi-level perspective. Academy of Management Annals, 7(1): 295-340.

Engel, J. S. 2015. Global clusters of innovation: Lessons from Silicon Valley. California Management Review, 57(2): 36-65.

Etzioni, A. 2004. From empire to community: A new approach to international relations. New York, NY: Palgrave Macmillan and Houndmills.

European Commission. 2013. Impact Assessment Report on the EU-China Investment Relations, Commission Staff Working Document SWD (2013)185 final. May 23. http:// ec.europa.eu/smart-regulation/impact/ia_carried_out/ docs/ia_2013/swd_2013_0185_en.pdf. Accessed 26 September 2018.

European Commission. 2018a. Report on the protection and enforcement of intellectual property rights in third countries, Commission Staff Working Document SWD (2018) 47 final. http://trade.ec.europa.eu/doclib/docs/2018/ march/tradoc 156634.pdf. Accessed 30 July 2018.

European Commission. 2018b. EU launches WTO case against China's unfair technology transfers. June 1 (Press Release). http://europa.eu/rapid/press-release_IP-18-4027 en.htm. Accessed 28 November 2018.

European Commission. 2019. EU-China-A strategic outlook. Joint communication to the European Parliament, the European Council and the Council. March 12. https:// ec.europa.eu/commission/sites/beta-political/files/ communication-eu-china-a-strategic-outlook.pdf

Ezell, S. 2011. Fighting innovation mercantilism. Issues in Science and Technology, 27(2): 83-90.

Feigenbaum, E. A. 2017. Is coercion the new normal in Chian's economic statecraft? Carnegie Endowment for International Peace. July 25. https://carnegieendowment.org/ 2017/07/25/is-coercion-new-normal-in-china-s-economicstatecraft-pub-72632. Accessed 15 October 2018.

Feng, E. 2019. How China acquired mastery of vital microchip technology. Financial Times. January 28. Retrieved from: https://www.ft.com/content/7cfb2f821ecc-11e9-b126-46fc3ad87c65

Ferraris, A. 2014. Rethinking the literature on "multiple embeddedness" and subsidiary-specific advantages. Multinational Business Review, 22(1): 15-33.

Filippaios, F., Annan-Diab, F., Hermidas, A., \& Theodoraki, C. 2019. Political governance, civil liberties, and human capital: Evaluating their effect on foreign direct 
investment in emerging and developing economies. Journal of International Business Studies, 59(7): 1103-1129.

Friedman, T. L. 2005. The world is flat: A brief history of the twenty-first century. New York, NY: Farrar, Straus and Giroux.

Gereffi, G. 2018. Global value chains and development: Redefining the contours of 21st century capitalism. Cambridge, UK: Cambridge University Press.

Gereffi, G., Humphrey, J., \& Sturgeon, T. 2005. The governance of global value chains. Review of International Political Economy, 12(1): 78-104.

Ghemawat, P. 2003. Semiglobalization and international business strategy. Journal of International Business Studies, 34(2): 138-152.

Ghemawat, P. 2007. Redefining global strategy: Crossing borders in a world where differences still matter. Boston, MA: Harvard Business Review Press.

Gooris, J., \& Peeters, C. 2016. Fragmenting global business processes: A protection for proprietary information. Journal of International Business Studies, 47(5): 535-562.

Hannas, W. C., Mulvenon, J. C., \& Puglisi, A. B. 2013. Chinese industrial espionage: Technology acquisition and military modernisation. New York, NY: Routledge.

Hart, T., \& Fazzani, L. 1997. Intellectual property law. London, UK: Macmillan Press.

Haveman, H. A., Jia, N., Shi, J., \& Wang, Y. 2017. The dynamics of political embeddedness in China. Administrative Science Quarterly, 62(1): 67-104.

Helfat, C. E., Finkelstein, S., Mitchell, W., Peteraf, M., Singh, H., Teece, D., et al. 2007. Dynamic capabilities: Understanding strategic change in organizations. New York, NY: Wiley.

Hennart, J. F. 1989. Can the "new forms of investment" substitute for the "old forms?" A transaction costs perspective. Journal of International Business Studies, 20(2): 211-234.

Hernandez, E., \& Guillén, M. F. 2018. What's theoretically novel about emerging-market multinationals? Journal of International Business Studies, 49(1): 24-33.

Herrero, A. G., \& Xu, J. 2019. Countries' perceptions of China's Belt and Road initiative: A big data analysis. Working paper, Bruegel, Issue 01. February 6. http:// bruegel.org/2019/02/countries-perceptions-of-chinas-beltand-road-initiative-a-big-data-analysis/.

Higgins, V. 2015. Beyond Neo-Techno Nationalism: An Introduction to China's Emergent Third Way: Globalized Adaptive Ecology, Emergent Capabilities and Policy Instruments. In: Alliance Capitalism, Innovation and the Chinese State. International Political Economy Series. London, UK: Palgrave Macmillan.

Horsman, M., \& Marshall, A. 1994. After the nation state: Citizens, tribalism and the new world disorder. London, UK: Harper Collins.

Hu, H. W., Cui, L., \& Aulakh, P. S. 2019. State capitalism and performance persistence of business group-affiliated firms: A comparative study of China and India. Journal of International Business Studies, 50(2): 193-222.

Hymer, S. H. 1976. International operations of national firms. Boston, MA: MIT Press

Jackson, G., \& Deeg, R. 2008. Comparing capitalisms: Understanding institutional diversity and its implications for international business. Journal of International Business Studies, 39(4): 540-561.

Jackson, G., \& Deeg, R. 2019. Comparing capitalisms and taking institutional context seriously. Journal of International Business Studies, 50(1): 4-19.

Jannace, W., \& Tiffany, P. 2019. A new world order: The rule or law, or the law of rulers? Fordham International Law Journal, 42(5): 1379-1417.

Joske, A. 2018. Picking flowers, making honey: The Chinese military's collaboration with foreign universities. Policy Brief Report No. 10/2018. Australian Strategic Policy Institute, 1-25.
Judge, W. Q., Fainshmidt, S., \& Brown, J. L., III. 2014. Which model of capitalism best delivers both wealth and equality? Journal of International Business Studies, 45(4): 363-386.

Kano, L. 2018. Global value chain governance: A relational perspective. Journal of International Business Studies, 49(6): 684-705.

Kaplan, R. D. 2019. A new cold war has begun: The United States and China will be locked in a contest for decades. But Washington can win if it stays more patient than Beijing. Foreign Policy. January 7. Retrieved from: https:// foreignpolicy.com/2019/01/07/a-new-cold-war-has-begun/.

Kaplinsky, R. 2013. What contribution can China make to inclusive growth in sub-Saharan Africa? Development and Change, 44(6): 1295-1316.

Kennedy, A. B. 2013. China's search for renewable energy: Pragmatic techno-nationalism. Asian Survey, 53(5): 909-930.

Kennedy, A. B. 2017. Unequal partners: US collaboration with China and India in research and development. Political Science Quarterly, 132(1): 63-86.

Knight, F. 1921. Risk, uncertainty and profit. Boston, MA and New York, NY: Houghton Mifflin.

Krugman, P., \& Obstfeld, M. 2000. International economics: Theory and practice. Boston, MA: Addison Wesley.

Lall. S. 2004. Reinventing industrial strategy: the role of government policy in building industrial competitiveness (No. 28. G-24 Discussion Paper Series. United Nations Conference on Trade and Development.

Lampert, C. M., Kim, M., Hubbard, T., Roy, R. \& Leckie, G. 2018. Fearlessly Swimming Upstream to Risky Waters: The Role of Geographic Entry in Innovation. Journal of Management Studies, advance online publication May 2.

Lema, R., Quadros, R., \& Schmitz, H. 2015. Reorganising global value chains and building innovation capabilities in Brazil and India. Research Policy, 44(7): 1376-1386.

Lessard, D., Teece, D. J., \& Leih, S. 2016. The dynamic capabilities of meta-multinationals. Global Strategy Journal, 6(3): 211-224.

Levine, S. S., Bernard, M., \& Nagel, R. 2017. Strategic intelligence: The cognitive capability to anticipate competitor behavior. Strategic Management Journal, 38(12): 2390-2423.

Lewin, A. Y., Kenney, M., \& Murmann, J. P. (Eds.). 2016. China's innovation challenge: Overcoming the middle-income trap. Cambridge, UK: Cambridge University Press.

Ligaya, A. 2019. Manulife's business in China not impacted by Ottawa-Beijing dispute: CEO. May 2. https://www. bnnbloomberg.ca/manulife-sales-surge-in-first-quarter-onback-of-strong-growth-in-asia-1.1252431. Accessed 3 May 2019.

Liu, X., Lu, J., Filatotchev, I., Buck, T., \& Wright, M. 2010. Returnee entrepreneurs, knowledge spillovers and innovation in high-tech firms in emerging economies. Journal of International Business Studies, 41(7): 1183-1197.

Livesey, F. 2018. Unpacking the possibilities of deglobalisation. Cambridge Journal of Regions, Economy and Society, 11(1): 177-187.

Lorenzoni, G., \& Lipparini, A. 1999. The leveraging of interfirm relationships as a distinctive organizational capability: A longitudinal study. Strategic Management Journal, 20(4): 317-338.

Lundan, S. M. 2018. From the editor: Engaging international business scholars with public policy issues. Journal of International Business Policy, 1(1): 1-11.

Lundan, S. M., \& Li, J. 2019. Adjusting to and learning from institutional diversity: Toward a capability-building perspective. Journal of International Business Studies, 50(1): $36-47$.

Luo, Y. 2000. Dynamic capabilities in international expansion. Journal of World Business, 35(4): 355-378. 
Luo, Y., \& Tung, R. 2018. A general theory of springboard MNEs. Journal of International Business Studies, 49(2): 129-152.

Mariotti, S., \& Marzano, R. 2019. Varieties of capitalism and the internationalization of state-owned enterprises. Journal of International Business Studies, 50(5): 669-691.

Mathews, J. A. 2002. Dragon multinational: A new model for global growth. New York, NY: Oxford University Press.

Mathews, J. A. 2005. The intellectual roots of latecomer industrial development. International Journal of Technology and Globalisation, 1(3-4): 433-450.

Mathews, J. A. 2006. Dragon multinationals: New players in 21st century globalization. Asia Pacific Journal of Management, 23(1): 5-27.

Mathews, J. A. 2017. Dragon multinationals powered by linkage, leverage and learning: A review and development. Asia Pacific Journal of Management, 34(4): 769-775.

Matysiak, L., Rugman, A. M., \& Bausch, A. 2018. Dynamic capabilities of multinational enterprises: The dominant logics behind sensing, seizing, and transforming matter! Management International Review, 58(2): 225-250.

McDermott, G., Mudambi, R., \& Parente, R. 2013. Strategic modularity and the architecture of multinational firm. Global Strategy Journal, 3(1): 1-7.

McKinnon, R. I. 2010. China in Africa: the Washington consensus versus the Beijing consensus. International Finance, 13(3): 495-506.

Mees-Buss, J., Welch, C., \& Westney, D. E. 2019. What happened to the transnational? The emergence of the neoglobal corporation. Journal of International Business Studies. https://doi.org/10.1057/s41267-019-00253-5.

Meyer, K. E. 2015. What is "strategic asset seeking FDI"? Multinational Business Review, 23(1): 57-66.

Meyer, K. E. 2017. International business in an era of antiglobalization. Multinational Business Review, 25(2): 78-90.

Meyer, K. E., Mudambi, R., \& Narula, R. 2011. Multinational enterprises and local contexts: The opportunities and challenges of multiple embeddedness. Journal of Management Studies, 48(2): 235-252.

Milliken, F. J. 1987. Three types of perceived uncertainty about the environment: State, effect, and response uncertainty. Academy of Management Review, 12(1): 133-143.

Mudambi, R., Li, L., Ma, X., Makino, S., Qian, G., \& Boschma, R. 2018. Zoom in, zoom out: Geographic scale and multinational activity. Journal of International Business Studies, 49(8): 929-941.

Mycek, S. 1999. Teetering on the edge of chaos: Giving up control and embracing uncertainty can lead to surprising creativity. Trustee: The Journal for Hospital Governing Boards, 52(4): 10-13.

Nager, A. 2016. Calling out China's Mercantilism. The International Economy, 30(2): 62-64.

Narula, R. 2003. Globalization and technology: Interdependence, innovation systems and industrial policy. Cambridge, UK: Polity Press.

Narula, R. 2006. Globalization, new ecologies, new zoologies, and the purported death of the eclectic paradigm. Asia Pacific Journal of Management, 23(2): 143-151.

Narula, R. 2014. Exploring the paradox of competencecreating subsidiaries: Balancing bandwidth and dispersion in MNEs. Long Range Planning, 47(1-2): 4-15.

Narula, R. 2017. Emerging market MNEs as meta-integrators: The importance of internal networks. International Journal of Technology Management, 74(1/2/3/4): 214-220.

Narula, R., \& Dunning, J. H. 2000. Industrial development, globalization and multinational enterprises: New realities for developing countries. Oxford Development Studies, 28(2): 141-167.

Narula, R., \& Santangelo, G. D. 2009. Location, collocation and $\mathrm{R} \& \mathrm{D}$ alliances in the European ICT industry. Research Policy, 38(2): 393-403.
Narula, R., \& Verbeke, A. 2015. Making internalization theory good for practice: The essence of Alan Rugman's contributions to international business. Journal of World Business, 50(4): 612-622.

Naughton, B., \& Tsai, K. S. (Eds.). 2015. State capitalism, institutional adaptation, and the Chinese miracle. Cambridge, UK: Cambridge University Press.

OECD. 2017. Business Insights on Emerging Markets 2017. OECD Development Centre, Paris, http://www.oecd.org/ dev/oecdemnet.htm. Accessed 10 March, 2019.

Oliver, C., \& Holzinger, I. 2008. The effectiveness of strategic political management: A dynamic capabilities framework. Academy of Management Review, 33(2): 496-520.

Ostry, S., \& Nelson, R. R. 1995. Techno-nationalism and Techno-globalism: Conflict and Cooperation. Washington, D.C.: Brookings Institution Press.

Ozawa, T. 2019. A note on Dani Rodrik, "Populism and the economics of globalization". Journal of International Business Policy, 2(2): 182-193.

Pack, H., \& Saggi, K. 2006. The case for industrial policy: A critical survey. The World Bank Research Observer, 21(2): 267-297.

Pagnattaro, M. A. 2012. Preventing know-how from walking out the door in China: Protection of trade secrets. Business Horizons, 55(4): 329-337.

Pandza, K., \& Thorpe, R. 2009. Creative search and strategic sense-making: Missing dimensions in the concept of dynamic capabilities. British Journal of Management, 20(S1): S118-S131.

Parente, R., Rong, K., Geleilate, J. M. G., \& Misati, E. 2019. Adapting and sustaining operations in weak institutional environments: A business ecosystem assessment of a Chinese MNE in Central Africa. Journal of International Business Studies, 50(2): 275-291.

Parrilli, M. D., Nadvi, K., \& Yeung, H. W. C. 2013. Local and regional development in global value chains, production networks and innovation networks: A comparative review and the challenges for future research. European Planning Studies, 21(7): 967-988.

Peng, M. W., Ahlstrom, D., Carraher, S. M., \& Shi, W. S. 2017. An institution-based view of global IPR history. Journal of International Business Studies, 48(7): 893-907.

Peterson, M. F., Søndergaard, M., \& Kara, A. 2018. Traversing cultural boundaries in IB: The complex relationships between explicit country and implicit cultural group boundaries at multiple levels. Journal of International Business Studies, 49(8): 1081-1099.

Petricevic, O., \& Verbeke, A. 2019. Unbundling dynamic capabilities for inter-organizational collaboration: The case of nanotechnology. Cross Cultural \& Strategic Management, 26(3): 422-448.

Pillsbury, M. 2015. The hundred-year marathon: China's secret strategy to replace America as the global superpower. New York, NY: Henry Holt and Company.

Pitelis, C. N., \& Teece, D. J. 2010. Cross-border market cocreation, dynamic capabilities and the entrepreneurial theory of the multinational enterprise. Industrial and Corporate Change, 19(4): 1247-1270.

Pitelis, C. N., \& Teece, D. J. 2018. The new MNE: 'Orchestration' theory as envelope of 'Internalisation' theory. Management International Review, 58(4): 523-539.

Prud'homme, D. 2019. Re-conceptualizing intellectual property regimes in international business research: Foreignfriendliness paradoxes facing MNCs in China. Journal of World Business, 54(4): 399-419.

Pye, L. W., \& Leites, N. 1982. Nuances in Chinese political culture. Asian Survey, 22(12): 1147-1165.

Rapoza, K. 2019. The unintended consequences of the China trade war. Forbes, June 26. Retrieved from: https://www. forbes.com/sites/kenrapoza/2019/06/26/the-unintendedconsequences-of-the-china-trade-war/\#46a040de6ba0. 
Reich, R. B. 1987. The rise of techno-nationalism. The Atlantic Monthly 259(5): 62-69.

Rosenberg, N., \& Birdzell, L. E. 1987. How the West Grew Rich: The economic transformation of the industrial world. New York, NY: Basic Books.

Rowley, T. J. 1997. Moving beyond dyadic ties: A network theory of stakeholder influences. Academy of Management Review, 22(4): 887-910.

Rugman, A., \& Oh, C. H. 2008. Friedman's follies: Insights on the globalization/regionalization debate. Business and politics, 10(2): 1-14.

Rugman, A., \& Verbeke, A. 1989. Strategic trade policy is not good strategy. Hitotsubashi Journal of Commerce and Management, 25(1): 75-97.

Rugman, A., \& Verbeke, A. 2003. Extending the theory of the multinational enterprises: Internalization theory and strategic management perspectives. Journal of International Business Studies, 34(2): 125-137.

Ryu, W., McCann, B. T., \& Reuer, J. J. 2018. Geographic colocation of partners and rivals: Implications for the design of R\&D alliances. Academy of Management Journal, 61(3): 945-965.

Schoemaker, P. J. H., Heaton, S., \& Teece, D. J. 2018. Innovation, dynamic capabilities, and leadership. California Management Review, 61(1): 15-42.

Schotter, A., \& Teagarden, M. 2014. Protecting intellectual property in China. MIT Sloan Management Review, 55(4): 41-48.

Schreyögg, G., \& Kliesch-Eberl, M. 2007. How dynamic can organizational capabilities be? towards a dual-process model of capability dynamization. Strategic Management Journal, 28(9): 913-933.

Schwartz, B. I. 1985. The world of thought in ancient China. Cambridge, MA: Belknap Press.

Shim, Y., \& Shin, D. H. 2016. Neo-techno nationalism: The case of China's handset industry. Telecommunications Policy, 40(2-3): 197-209.

Singh, J. 2008. Distributed R\&D, cross-regional knowledge integration and quality of innovative output. Research Policy, 37(1): 77-96.

Sojli, E., \& Tham, W. W. 2017. Foreign political connections. Journal of International Business Studies, 48(2): 244-266.

Storz, C., Amable, B., Casper, S., \& Lechevalier, S. 2013. Bringing Asia into the comparative capitalism perspective. Socio-Economic Review, 11(2): 217-232.

Strange, C. 1996. The retreat of the state: The diffusion power in the world economy. Cambridge, UK: Cambridge University Press.

Sturm, R. E., Vera, D., \& Crossan, M. 2017. The entanglement of leader character and leader competence and its impact on performance. The Leadership Quarterly, 28(3): 349-366.

Suttmeier, R., Yao, X., \& Tan, A. Z. 2004. China's Post-WTO Technology Policy: Standards, Software and the Changing Nature of Techno-Nationalism. The National Bureau of Asian Research, Special Report, No. 7.

Taylor, I. 2007. China and Africa: Engagement and compromise. Abingdon, UK and New York, NY: Routledge.

Teece, D. J. 1986a. Profiting from technological innovation: Implications for integration, collaboration, licensing and public policy. Research Policy, 15(6): 285-305.

Teece, D. J. 1986b. Transaction cost economics and the multinational enterprise: An assessment. Journal of Economic Behavior \& Organization, 7(1): 21-45.

Teece D. J. 1991. Support Policies for Strategic Industries: Impact on Home Economies. In OECD International Futures Programme. Strategic Industries in a Global Economy: Policy Issues for the 1990s, CEDEX, Paris.

Teece, D. J. 2007. Explicating dynamic capabilities: The nature and microfoundations of (sustainable) enterprise performance. Strategic Management Journal, 28(13): 1319-1350.

Teece, D. J. 2014. A dynamic capabilities-based entrepreneurial theory of the multinational enterprise. Journal of International Business Studies, 45(1): 8-37.
Teece, D. J. 2016. Dynamic capabilities and entrepreneurial management in large organizations: Toward a theory of the (entrepreneurial) firm. European Economic Review, 86: 202-216.

Teece, D. J. 2018a. Profiting from innovation in the digital economy: Enabling technologies, standards, and licensing models in the wireless world. Research Policy, 47(8): 1367-1387.

Teece, D. J. 2018b. Dynamic capabilities as (workable) management systems theory. Journal of Management \& Organization, 24(3): 359-368.

Teece, D. J., Peteraf, M., \& Leih, S. 2016. Dynamic capabilities and organizational agility: Risk, uncertainty, and strategy in the innovation economy. California Management Review, 58(4): 13-35.

Teece, D. J., Pisano, G., \& Shuen, A. 1997. Dynamic capabilities and strategic management. Strategic Management Journal, 18(7): 509-533.

The Economist. 2017. The retreat of the global company: Briefing multinationals. January 28: 18-22.

The Economist. 2018a. Chinese investment, and influence, in Europe is growing.

The Economist. 2018b. A trade truce between America and China is over as soon as it began.

van der Putten, F-P. 2017. Chinese direct investment in the Netherlands: Patterns, reception and political significance. Clingendael Netherlands Institute of International Relations. Policy Brief, December 22. https://www.clingendael.org/ publication/chinese-direct-investment-netherlands Accessed 8 December 2018

van Tulder, R., Verbeke, A. \& Jankowska B. (Eds.). 2020. International Business in a VUCA World. PIBR, Volume 14 Bingley, UK: Emerald Publishing.

Verbeke, A. 2013. International business strategy (2nd ed.). Cambridge, UK: Cambridge University Press.

Verbeke, A., Coeurderoy, R., \& Matt, T. 2018. The future of international business research on corporate globalization that never was.... Journal of International Business Studies, 49(9): 1101-1112.

Vernon, R. 1966. International trade and international investment in the product cycle. Quarterly Journal of Economics, 80(2): 190-207.

Vernon, R. 1971. Sovereignty at bay: The multinational spread of US enterprises. New York, NY: Basic Books.

Vernon, R., \& Wells, L. T. 1986. The economic environment of international business (4th ed.). Englewood Cliffs, NJ: Prentice-Hall.

von Zedtwitz, M., Corsi, S., Søberg, P. V., \& Frega, R. 2015. A typology of reverse innovation. Journal of Product Innovation Management, 32(1): 12-28.

Wang, C., Hong, J., Kafouros, M., \& Wright, M. 2012. Exploring the role of government involvement in outward FDI from emerging economies. Journal of International Business Studies, 43(7): 655-676.

Wei, T., Clegg, J., \& Ma, L. 2015. The conscious and unconscious facilitating role of the Chinese government in shaping the internationalization of Chinese MNCs. International Business Review, 24(2): 331-343.

Wei, L., \& Davis, B. 2018. How China systematically pries technology from U.S. companies. Wall Street Journal Eastern Edition, September 27.

Weiss, P. 1997. Techno-globalism and industrial policy responses in the USA and Europe. Intereconomics, 32(2): 74-86.

Wernau, J. 2019. Forced tech transfers are on the rise in China (p. 20). Wall Street Journal, May: European Firms Say.

White House Office of Trade and Manufacturing Policy. 2018. How China's economic aggression threatens the technologies and intellectual property of the United States and the world. https://www.whitehouse.gov/wp-content/ uploads/2018/06/FINAL-China-Technology-Report-6.18. 18-PDF.pdf. Accessed 30 July 2018. 
Williamson, J. 1993. Democracy and the "Washington consensus". World Development, 21(8): 1329-1336.

Wilson, M., Kannangara, K., Smith, G., Simmons, M., \& Raguse, B. 2002. Nanotechnology: Basic science and emerging technologies. Boca Raton, FL: Chapman and Hall/CRC.

Witt, M. A. 2019. De-globalization: Theories, predictions, and opportunities for international Business research. Journal of International Business Studies, 50(7): 1053-1077.

Wong, C. H., \& Dou, E. 2017. Foreign companies in China Get a New Partner: The Communist Party. Wall Street Journal Eastern Edition, October 30.

Zenglein, M. J., \& Holzmann, A. 2019. Evolving Made in China 2025. Mercator Institute for China Studies (MERICS), Papers on China, No. 8. July. https://www.merics.org/sites/ default/files/201907/MPOC_8_MadeinChina_2025_final. pdf.

Zhou, Y., Lazonick, W., \& Sun, Y. (Eds.). 2016. China as an innovation nation. Oxford, UK: Oxford University Press.

Zollo, M., Bettinazzi, E. L., Neumann, K., \& Snoeren, P. 2016. Toward a comprehensive model of organziational evolution: Dynamic capabilities for innovation and adaptation of the enterprise model. Global Strategy Journal, 6(3): 225-244.

Zollo, M., \& Winter, S. G. 2002. Deliberate learning and the evolution of dynamic capabilities. Organization Science, 13(3): 339-351.

\section{ABOUT THE AUTHORS}

Olga Petricevic, PhD is an Assistant Professor at the University of Calgary. Her current and published work examines the nature and the role of dynamic capabilities in the context of high-technology firms and by adopting interdisciplinary perspectives. She currently serves on the Editorial Boards of several leading academic journals.

David J. Teece, PhD is the Thomas W. Tusher Professor in Global Business and the Director of the Tusher Center initiative for the Management of Intellectual Capital, Haas School of Business, University of California, Berkeley. He is also chairman of the Berkeley Research Group, and has published over 30 books and over 200 articles on the role of innovation, technical change, and capabilities in the competitive performance of the business enterprise, and on domestic and international policy. He has also published extensively on public policy and governance.

Open Access This article is distributed under the terms of the Creative Commons Attribution 4.0 International License (http://creativecommons.org/licenses/by/4.0/), which permits unrestricted use, distribution, and reproduction in any medium, provided you give appropriate credit to the original author(s) and the source, provide a link to the Creative Commons license, and indicate if changes were made.

Publisher's Note Springer Nature remains neutral with regard to jurisdictional claims in published maps and institutional affiliations.

Accepted by Rajneesh Narula, Area Editor, 16 August 2019. This article has been with the authors for three revisions. 